Article

\title{
Forest Cover Change, Households' Livelihoods, Trade-Offs, and Constraints Associated with Plantation Forests in Poor Upland-Rural Landscapes: Evidence from North Central Vietnam
}

\author{
Quy Van Khuc ${ }^{1, *(1)}$, Tuyet-Anh T. Le ${ }^{2}$, Trung H. Nguyen ${ }^{3}{ }^{(0}$, Duy Nong ${ }^{4}$, Bao Quang Tran ${ }^{5}$,
}

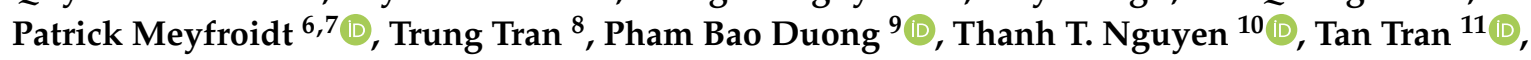
Linh Pham ${ }^{12}$, Shawn Leu ${ }^{13} \mathbb{1}$, Ngo Thi Phuong Thao ${ }^{14}$, Nguyen Huu-Dung ${ }^{14}$, Trung-Kien Dao ${ }^{1}{ }^{10}$, Nguyen Van Hong ${ }^{15}$, Bui Thi Minh Nguyet ${ }^{16}$, Hoai-Son Nguyen ${ }^{17}$ and Mark W. Paschke ${ }^{18}$

1 Faculty of Economics and Business, PHENIKAA University, Hanoi 12116, Vietnam;

kien.daotrung@phenikaa-uni.edu.vn

2 Department of Environmental Science, Memorial University of Newfoundland, NL A1C 5S7, Canada; tatle@mun.ca

3 Department of Soils and Crop Sciences, Colorado State University, Fort Collins, CO 80523, USA; nguyentrung1710@gmail.com

4 Agriculture and Food, The Commonwealth Scientific and Industrial Research Organisation, St Lucia, Brisbane 4067, Australia; duy.nong@csiro.au

5 Faculty of Environment and Forest Resource Management, Vietnam National University of Forestry, Hanoi 100000, Vietnam; baofuv@vnuf.edu.vn

6 Georges Lemaître Center for Earth and Climate Research, Earth and Life Institute, Université Catholique de Louvain, 1348 Louvain-la-Neuve, Belgium; patrick.meyfroidt@uclouvain.be

7 Fonds de la Recherche Scientifique - F.R.S.-FNRS, 1000 Brussels, Belgium

8 School of Civil and Environmental Engineering, University of Ulsan, Ulsan 44610, Korea; tranductrung.csu@gmail.com

9 Faculty of Economics and Rural Development, Vietnam National University of Agriculture, Hanoi 100000, Vietnam; pbduong@vnua.edu.vn

10 Institute for Environmental Economics and World Trade, Leibniz University Hannover, 30167 Hannover, Germany; thanh.nguyen@iuw.uni-hannover.de

11 Department of Mathematical Sciences, Montana State University, Bozeman, MT 59717, USA; vinhtantran@gmail.com

12 Department of Economics, University of Central Oklahoma, Edmond, OK 73034, USA; lpham17@uco.edu

13 UNE Business School, University of New England, Armidale NSW 2351, Australia; cleu@une.edu.au

14 Faculty of Real Estate and Natural Resource Economics, National Economics University, Hanoi 100000, Vietnam; thaonp@neu.edu.vn (N.T.P.T.); nguyen.huudungforest@gmail.com (N.H.-D.)

15 Department of Landscape and Ecology, Institute of Geography, Vietnam Academy of Science and Technology, Hanoi 100000, Vietnam; nguyenhong.ig@gmail.com

16 Faculty of Economics and Business Administration, Vietnam National University of Forestry, Hanoi 100000, Vietnam; minhnguyetfuv@gmail.com

17 Faculty of Economics, National Economics University, Hanoi 100000, Vietnam; hoaisonkt@gmail.com

18 Department of Forest and Rangeland Stewardship, Colorado State University, Fort Collins, CO 80523, USA; Mark.Paschke@colostate.edu

* Correspondence: quy.khucvan@phenikaa-uni.edu.vn

Received: 11 January 2020; Accepted: 8 May 2020; Published: 13 May 2020

check for updates

Abstract: Vietnam's forests have experienced a notable transformation over the past 20 years from net deforestation to reforestation and expanding forests. Continued reforestation that aims to achieve further economic and environmental benefits remains a national priority and strategy. We explore the current status of plantation forests and highlight possible means to facilitate their expansion in the 
uplands of Vietnam. We employ mixed method triangulation to empirically explore plantation forests and their economic role in household livelihood, to quantify trade-offs between plantation forests and shifting cultivation, and to assess the constraints on plantation forest expansion in Nghe An province, north-central Vietnam. Results show that forest in the study area expanded by 406,000 ha (71.1\%) between 1990 and 2016. Plantation forests increased by nearly 500\% (from 32,000 ha to 190,000 ha), while natural forests expanded by $48.1 \%$ (from 538,000 ha to 797,000 ha). Plantation forests contributed an average of 35.1 percent of total household income in wealthier households and 27.9 percent of income in poor households. Switching from shifting cultivation to plantation forests would increase total household income and average carbon stock but decrease food provision. Total Economic Value would be higher for plantation forest scenarios if increased carbon stocks in plantations can be monetized. This carbon income might drive conversion of shifting cultivation to plantation forests. Constraints on further expansion of plantation forest are low external cooperation, education, market stability, and agroforestry extension services. Our empirical results inform national plantation forest development, sustainable upland livelihood development, and climate change mitigation programs to ultimately facilitate forest transition and improve the resilience and sustainability of socio-ecological systems.

Keywords: forest transition; plantation forest solutions; principal component analysis; rural livelihood; trade-offs; Vietnam

\section{Introduction}

Globally, there is a need to reverse deforestation and increase the area of forests to meet Sustainable Development Goals (SDGs) such as economic growth, poverty reduction, and global environmental improvement [1-6]. Reforestation and afforestation are also worldwide objectives to mitigate the increasingly adverse effects of climate change. Therefore, a better understanding of forest expansion solutions is a key requirement for designing proper forest-based climate solutions and sustainable rural development strategies.

Vietnam is one of the fastest-growing economies in the world and has made significant progress in forest cover expansion. The total forest area increased from almost 9.5 million ha $(28.7 \%$ of the land surface in Vietnam) in 1990 to 14 million ha (42\% of the land surface) in 2015 [7,8]. Although plantation forests have expanded considerably, numerous concerns regarding plantation forests development still remain in Vietnam. First, although total forest areas have expanded rapidly, there has been much less development in remote and poor upland areas causing imbalance in development levels between regions $[9,10]$. Second, most forest planters are still poor, and they are not able to realize additional values such as carbon values from plantation forests. They also face several (financial and land) constraints that prevent them from increasing income from agroforestry practices [11,12]. Third, even in the same upland area, however, due to several reasons such as market access, topography or other constraints, plantation forests have developed unevenly between regions. For example, the area of forests planted in the northeast was much larger than that in the northwest during 1999-2013 [10]. While the slow expansion of plantation forests in the upland area reflects the limits of agroforestry policies, the limited involvement of farmers in plantation forests together with existing financial constraints may hamper the goals to achieve, to some extent, climate change mitigation, poverty reduction, and sustainable mountainous rural development in Vietnam [13].

An overarching research question arises as to whether plantation forests have the potential to expand in poor mountainous communes to contribute to improving household income, increasing the value of plantation forests and mitigating climate change. To better answer this research question, we first review recent relevant studies to find evidence of plantation forest expansion and its factors during the last two decades. It is a fact that several studies on upland forests and human systems have 
been conducted in Vietnam. Some studies focused on exploring land cover change (forest transition) and its drivers $[7,10,14-17]$, while others studied the process of forest land allocation policy that facilitates forest land tenure evolution and land privatization [18-23]. At the same time, numerous studies investigated the factors influencing the adoption of tree plantation $[7,24-26]$; evaluated the economic value of forests [4,27-29]; and estimated the impact or efficiency of policies such as Reducing Emission from Deforestation and Forest Degradation (REDD+) and Payment for Ecosystem Service (PES) [30-34]. To date, however, there have only been a few comprehensive studies that have examined plantation forest solutions in conjunction with household participation in Vietnam [22,25]. Contemporary understanding of plantation forests remains sporadic and unsystematic. Furthermore, opportunities and constraints associated with plantation forest expansion in remote communes have either been less frequently studied or completely overlooked.

In this paper, we aimed to advance knowledge about plantation forests and issues associated with accelerating forest expansion in poor communes in Vietnam. We sought to answer four specific research questions: (1) To what extent have plantation forests increased or decreased in rural and remote communes? (2) How important are plantation forests to livelihoods? (3) What are the trade-offs between forest land use options? (4) What are the constraints on further expanding plantation forests?

Among 63 provinces in Vietnam, Nghe An was chosen as a study region because it has the high potential land for afforestation and reforestation [16]. Additionally, due to high poverty rate, poor governance and high population density, deforestation and forest degradation are taking place at high intensity in this province, with a total area of nearly 129,600 ha being deforested or degraded between 2000 and 2010 [35]. We used data from various sources including literature review, field measurement, household surveys, and group discussion. We employed the mixed method triangulation approach to address these research questions.

The remainder of the paper is organized as follows. Section 2 provides the background on the upland use system and key agroforestry policies. Section 3 develops and clarifies the plantation forest expansion framework. Section 4 describes the database-collecting-and-analyzing method used. Section 5 presents empirical results corresponding to the 4 respective research questions. Section 6 provides a discussion and acknowledges the study limitation. Section 7 summarizes the empirical findings and proposes some future study directions.

\section{Changes in Upland Use System and Agroforestry Policies Background}

Shifting cultivation and forest practices (forests-related practices) are two main components of upland use system in many places in Vietnam. Shifting cultivation, also known as "Swidden agriculture", refers to a rotational farming technique in which forestland is cleared for cultivation, normally by fire, and then allowed to lie fallow to regenerate for a few years. Shifting cultivation was closely linked to the expansion of agricultural land in forested regions, which had become a common pathway for household income, particularly in mountainous regions.

Since land reform in the forestry sector was implemented in 1995, forestland was allocated to all stakeholders in the economy, including individuals, households, and forest enterprises (Figure 1). Land privatization has prompted changes in forest management in Vietnam [22]. Forest-based economic development gradually became an important income option for many households in addition to traditional shifting cultivation, paddy rice, or other permanent cultivation (e.g., maize, fruit tree, etc.). In parallel with forestland reform, the government actively implemented several programs of forest rehabilitation and afforestation (programs 327, 661, and others) [7]. At the same time, plantation forest projects supported by many international organizations were implemented. These caused a large transition in Vietnam's forests, with the national forest cover rate increasing from $27.2 \%$ in 1990 to $39.5 \%$ in 2015 [8]. 


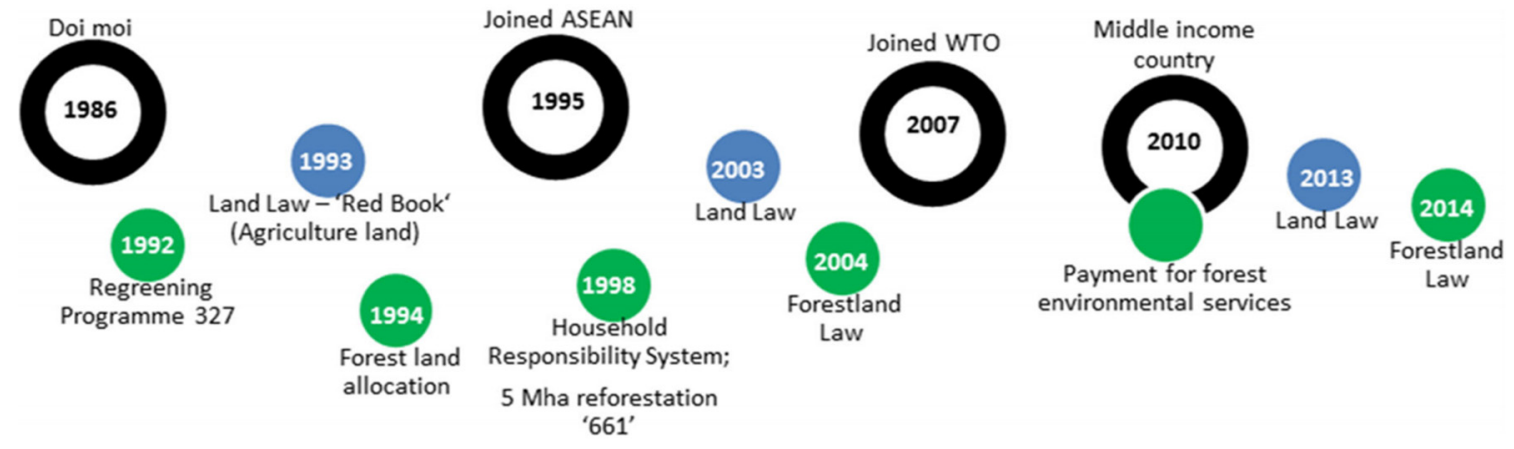

Figure 1. Major agroforestry policy milestones since 1986, sources [26]. "Doi moi" refers to "the economic reforms" initiated in Vietnam where its goal is to create a "socialist-oriented market economy". ASEAN stands for "Association of Southeast Asian Nations". WTO refers to "World Trade Organization".

Shifting cultivation has been practiced for centuries. Among a total of 54 ethnic groups, 50 groups have practiced shifting cultivation with around 2.8 million farmers in almost 0.5 million households. While only a few of the Kinh people, the majority ethnic group, are thought to practice shifting agriculture, the percentage of people in the other ethnic groups practicing shifting cultivation in the early 1990s were 7\% (Tay), 16\% (Nung), 45\% (Thai) and 100\% (almost all the remaining ethnic groups) [36]. There are two main types of shifting cultivation-pioneer shifting cultivation and rotational shifting cultivation. Pioneer shifting cultivation refers to the full use of soil fertility; the land is then abandoned without further intended use by the same cultivators. This type of shifting cultivation has been mainly practiced by the H'Mong people living in high mountains. Rotational shifting cultivation has been utilized by most of the remaining ethnic groups, where the fallowing period is usually 10-15 years, depending on conditions.

Although forest practices have a long history in Vietnam, forest management (forest protection, planting forests) has been promoted for only the past two decades. Remarkably, forest transition in Vietnam has occurred since the 1990s, at the same time as the introduction of land laws $(1993,2003)$ and forest protection and management laws $(1991,2004)$. A critical point highlighted in these laws is that the legal rights of many agents-individuals, households, forest enterprises-were acknowledged and forestland was clearly classified as either special forest land, production forest, or protected forest. At the national level, an increase in forest cover has been attributed to two national forest development programs: The Greening the Barren Hills program (program 327) and the Five Million Hectare Reforestation Project (5MHRP). Program 327 commenced and finished during the 1990s, while the 5MHRP began in 1998 and ended in $2010[7,26]$. Household involvement was encouraged in planting and protecting forests in the 327 and 5MHRP programs. The state made two offers to farmers: (1) to receive degraded forestland (bare land) on which to plant forests or (2) to receive forest land to protect. For the first option, farmers received 1 million VND (\$80) per ha for forestlands under natural regeneration with additional tree-planting and 2.5 million VND (\$208) per ha for forestlands under afforestation [37]. For the second option, people were paid 50 thousand VND (\$4.20) for protecting of 1 ha of forest per year. This level of support increased over time depending on the socioeconomic conditions of each region and locale (e.g., in Dien Bien farmers received 192 thousand VND (\$9.80) for the protection of 1 ha of forest per year). Furthermore, households could benefit from a certain share of timber and non-timber forest products (firewood, bamboo shoots, honey, medicinal herbs, etc.).

Generally speaking, these national forest programs were somewhat successful in terms of their contribution to increasing national forest cover, however, their impact on improving livelihoods has been questioned [24]. In summary, shifting cultivation and plantation forests have drastically changed in the last two decades. This land transition (shifting cultivation-to-forest practices transition) reveals the dynamic upland system and also reflects the effectiveness and/or impact of the lasting multiple socio-economic and forestry policies in the upland context in Vietnam. 


\section{The Framework of Plantation Forest Expansion}

The conceptual framework of plantation forest expansion refers to a set of conditions, procedures, and interactions. Forest practice, which is considered a household income maximization strategy, has broadly shaped the rural dynamic socio-ecological systems and/or increasingly contributed to the successful rural transformation [14,38-40]. Forest management practice involves stakeholders (farmers) whose behavior is related to choices and decisions [41], as well as production inputs (e.g., land, seedling, etc.), arrangements (e.g., organizing and/or implementing a forests-planting plan), and outcomes (e.g., wood, carbon, revenue, etc.). When farmers choose land use options, they try to maximize their benefits or outcomes. Smallholder adoption of plantation forest practices depends a range of factors influencing farmer decisions. First, farmers would choose to adopt plantation forest practices if the economic returns from doing so are higher, compared to alternative options $[25,42,43]$. Second, policy and risk also influence the success of plantation forest practices [43]. During the last two decades, socioeconomic reforms and forestland allocation policies have facilitated upland forest land tenure associated with land ownership devolution. Climate mitigation programs (e.g., REDD+) create an opportunity for farmers to earn incrementally financial benefits, while many other national forestry and rural development programs gradually empower farmers through several means, such as agroforestry extension practices and rural credit access [44]. The extent of plantation forest expansion is a subject of interest which is proportionally associated with the extent to which the above conditions are satisfied.

The core aim of our paper is to highlight potential means for expanding plantation forests in the rural mountain context. A mixed method triangulation approach was used involving analysis of biophysical data on the change in forest cover and carbon stocks, quantitative data on household income, and qualitative data on barriers to expanding plantations. We choose this approach for our analysis because the mixed method results in robust findings [45]. Specifically, we propose a methodological framework of plantation forest expansion solutions in five 'building-blocks' (Figure 2). The study begins with an examination of changes in forests between 1990 and 2016, including plantation and natural forests. Secondly, the role of planting forests, which corresponds to economic contributions of plantation forests to the livelihood of farmers, is examined. If the economic contribution is sufficiently large and significant, plantation forests are more likely to be adopted by local farmers [22,25]. Thirdly, we identify the opportunity associated with plantation forests. Specifically, we identify the opportunity cost and trade-offs of plantation forests by comparing the cost and benefit between plantation forests and alternative land use options (e.g., shifting cultivation). When plantation forests yield a higher economic benefit than the alternatives, there is a higher chance that plantation forests will be preferred/adopted by farmers. Yet this may not be the case for many farmers who have frequently suffered significant food shortages, as having enough food is often their prime interest [46]. Hence, the likelihood of plantation forest expansion requires further assessment under the lens of food shortage and household income. Fourthly, we analyze the constraints associated with plantation forest adoption. Even though farmers desire to join a forest plantation program, it does not ensure that plantation forests are successfully implemented or achieved because of constraints such as capital, labor, market, natural disasters, etc. [12,47]. Lastly, the mixed-method framework that considers livelihood, trade-off, and constraints analysis allowed us to identify the potential solutions of plantation forest expansion and a suite of recommended policies for upland plantation forest development. 


\section{Mixed methods triangulation}

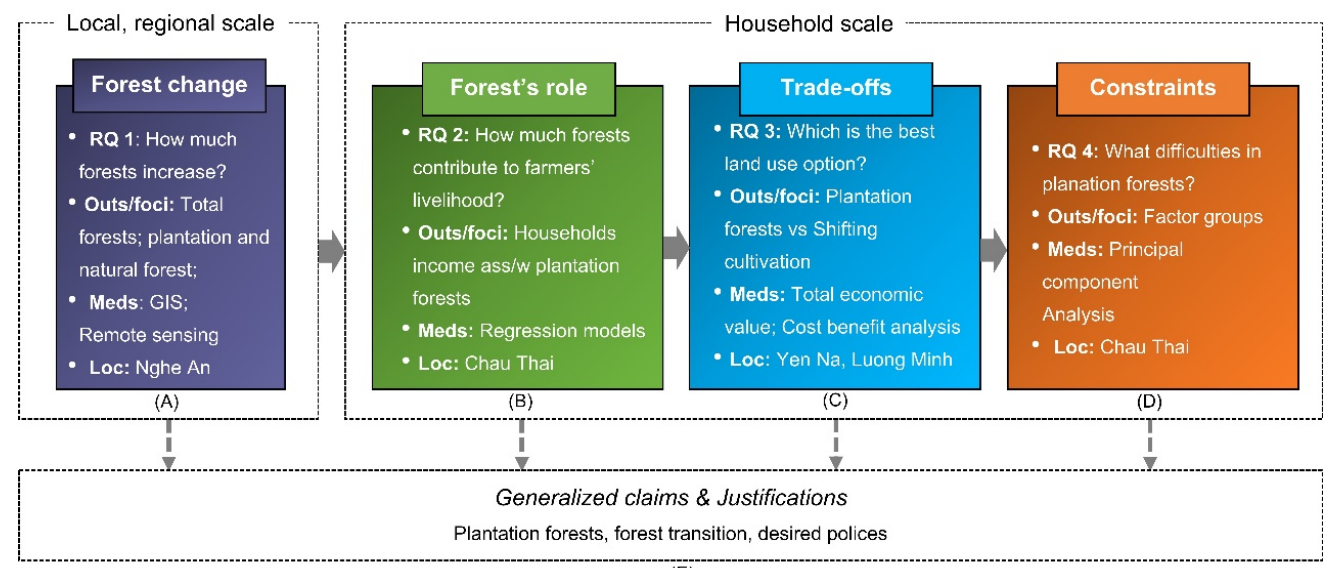

(E)

Figure 2. The logic of producing generalized claims of upland plantation forest expansion derived from the empirical analysis of forest change (A), forests' role (B), trade-offs $(\mathbf{C})$, and constraints (D). RQ, Outs/foci, Meds, Loc stands for 'research question, outcomes/focus, methods, location' respectively.

\section{Methods}

\subsection{Study Area}

The highly mountainous areas in Nghe An province was selected as the study region. It is noted that province is the largest administrative unit, followed by districts and commune units, where the latter represents the smallest administrative unit in Vietnam. Nghe An has many communes with challenging conditions such as high shares of remote communities with high poverty and limited forest development (Tables S1 and S2). The choice of specific communes was made based on discussions with district and commune leaders, as well as land use status, ethnic diversity, and availability of official data for all communes. High rate of poverty is an important criterion, so among 206 poor communes of Nghe An [48], we selected 3 communes (Chau Thai, Yen Na, and Luong Minh) for this empirical study (Table 1; Figure 3).

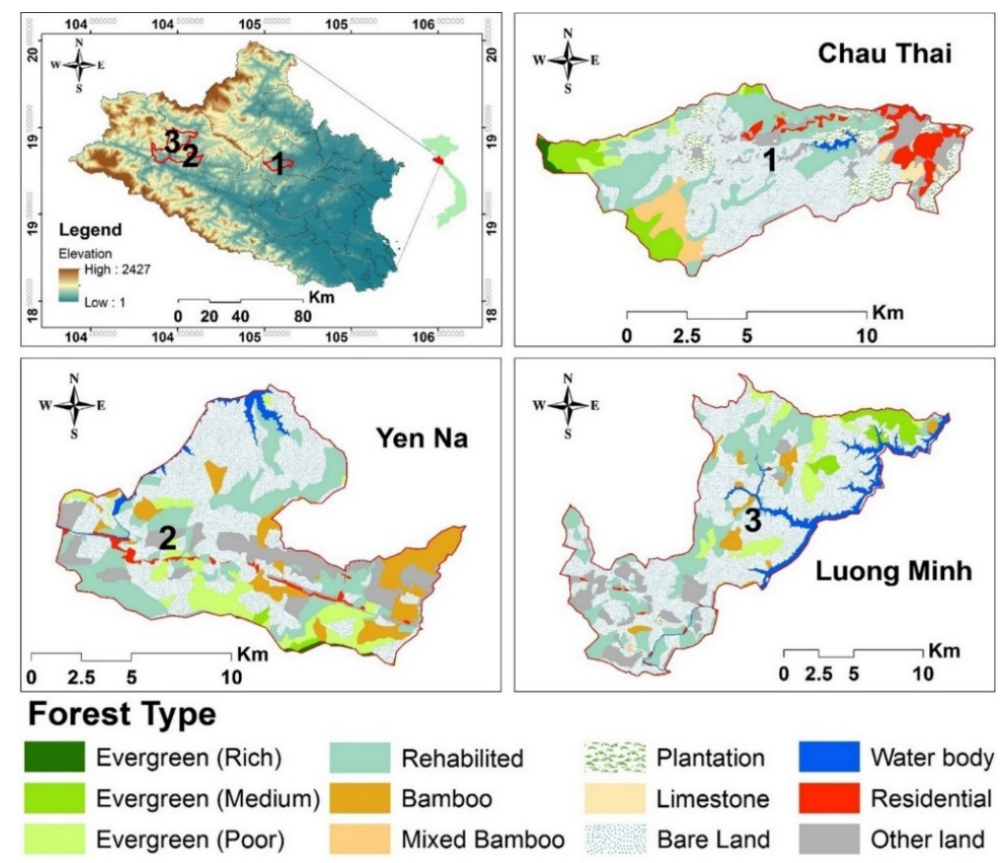

Figure 3. Map of study location. The study sites of 1, 2, 3 stands for communes of Chau Thai, Yen Na, and Luong Minh, respectively. 12 land use types are mapped for each commune. 
Table 1. Key features of the study area.

\begin{tabular}{cccc}
\hline \multirow{2}{*}{ Dimensions } & \multicolumn{2}{c}{ The Similarities and Differences of 3 Communes } \\
\cline { 2 - 4 } & Chau Thai (Site 1) & Yen Na (Site 2) & Luong Minh (Site 3) \\
\hline Condition & Poor commune & Poor commune & Poor commune \\
Agricultural land & 622 ha & 507 ha & 610 ha \\
& $(8.11 \%$ of total land) & $(3.60 \%$ of total land) & $(2.66 \%$ of total land) \\
Forestland land & 6447 ha & 6446 ha & 11,786 ha \\
Forestland allocated & $(84.11 \%$ of total land $)$ & $(45.81 \%$ of total land) & $(51.51 \%$ of total land) \\
The only land use practice & Since 1998 & Since 2003 & Since 2004 \\
& Plantation forests & Shifting cultivation & Shifting cultivation \\
\hline
\end{tabular}

- Site 1 is situated in Chau Thai commune (Quy Hop district). Primary forest has been cut for shifting cultivation and selective harvesting for a long time. Because of good soil conditions and low intensity shifting cultivation, forest in this area regenerates rapidly on fallow land. The natural forest was burned for shifting cultivation several times in rotation, with high intensity that created bare land, shrubland, and degraded forest. Since 1998, forests and forest lands have been allocated to the Youth Union in Nghe An province. Bare land has been used for reforestation purposes, but due to a lack of funds and labor, a large area of bare land remains untouched (Field survey).

- $\quad$ Site 2 is situated in Yen Na commune (Tuong Duong district). Before 1990, natural forest, except for rocky mountainous forests, was cut for shifting cultivation in several rotations. At that time, those areas formed mosaics between open areas and fallow lands. Forest land was also managed by the local governments. From 1990 to 2002, people freely burned forests for shifting cultivation and cut timber for building houses. Some areas, however, were protected by village regulation. Since 2003, forests and forestland have been allocated to households by the Decree No.163/1999/NĐ-CP of the State Government. Farmers invested in their allocated forestland using their own financial capital and/or financial support provided by the government. Shifting cultivation areas have been planned and controlled by local government.

- $\quad$ Site 3 is located in Luong Minh commune (Tuong Duong district). Before 1990, this area included rich forest ecosystems with standing stock over $200 \mathrm{~m}^{3} \mathrm{ha}^{-1}$. Between 1990 and 2003, forests and forestlands were allocated to local authorities with the goal of reducing deforestation (e.g., for harvesting timber). During this period, however, the forest area was significantly reduced due to rapid population growth, shifting cultivation, an expanded and rebuilt road system, and exploitation by local households and state companies. Since 2004, the forests and forestlands have been assigned to the Tuong Duong Forest Protection Management Board to protect against illegal exploitation and deforestation from agricultural expansion. However, the remaining forest areas have experienced degradation because illegal activities have not been entirely eliminated (Field survey).

Up to 2019, it is estimated that Nghe An has roughly 165 thousand ha of Acacia hybrids [49]. In Chau Thai commune most farmers plant $A$. hybrids in their allocated forestland. This is because A. hybrids is a fast-growing species that it often takes roughly 5-7 years to be harvested. In this region, most $A$. hybrids are traded and used for the pulpwood production. Although forest products are sold favorably on the market, farmers get relatively low returns due to high transportation costs.

\subsection{Data}

Our study used a wide range of data from three main sources, that is, official sources, literature review and field survey from 2012 to 2018, across 3 locations in Yen Na, Luong Minh and Chau Thai communes. The following sections present the description of our data and a set of procedures to obtain each data point in light of multiple objectives linked to the integrated methods approach (Figure 2). 


\subsubsection{GIS Data}

We used a forest distribution map to quantify plantation forests, natural forests, and total forests in Nghe An province for the period in 1990-2016. The data was sourced from a 5-year-cycle national forest inventory program that was implemented by the Forest Inventory and Planning Institute (FIPI) and the Japanese International Cooperation Agency (JICA). JICA and FIPI constructed forest distribution maps in 1990, 2000, 2010, and 2016 based on a forest classification system with 17 categories. The maps were made using a visual interpretation of relevant satellite images such as Thematic Mapper (TM), Advanced Land Observing Satellite (ALOS), and Satellite Pour l'Observation de la Terre, French for "Earth observation satellite" (SPOT) and ground truthing. We use the definition in Vietnamese Circular No.34/2009/TT-BNNPTNT, which identifies 'forests' as areas including newly planted forests with woody trees, regenerating forests after harvesting, and plantation forests with an average tree height of more than $1.5 \mathrm{~m}$ for slow-growing species and more than $3.0 \mathrm{~m}$ for fast-growing species, with a density of 1000 trees or more per hectare. Natural forests are already present or grew by natural regeneration; plantation forests are formed by humans. Forest distribution maps were officially checked for consistency in interpretation by the two parties when they were made, and it was found that classification consistency was at $89 \%$ between the two parties [50].

\subsubsection{Socioeconomic Data}

We conducted household surveys in 2012 and 2018. As shown in the conceptual framework (Figure 2), the first survey aimed to obtain information on shifting cultivation, which was used to carry out a trade-off analysis of plantation forests. The second survey collected data on household livelihoods and forest practices to evaluate the strengths and challenges of plantation forests. To make the empirical results of income analysis robust, we used the same interview method with a set of questionnaires for both surveys. Monetary values such as incomes were converted to be comparable. We used 2012 as the base year and converted income data from 2018 to this base year 2012 using common inflation rates from the State bank of $8 \%$. The survey was carefully prepared, including a pilot survey, a suite of questionnaires, and a focus group [51]. With timely interaction and exchange having taken place during the time the work was completed, a short face-to-face meeting with survey group members at the end of each working day was conducted throughout the duration of the survey to ensure progress for the following working days and the entire survey. We considered three key criteria in selecting households for an interview: (1) Households (respondents) were available to be interviewed; (2) Respondent could understand and respond to the questionnaire; (3) Households involved either shifting cultivation or plantation forests, or both.

For the first survey in 2012 in Tuong Duong district, we interviewed a total of 35 households, including 15 farmers in Luong Minh commune and 20 farmers in Yen Na commune. Households were classified into two income categories-poor and non-poor-and their shifting cultivation activities were recorded. Poor households in rural areas are households with an average income under $\$ 1.02$ per capita per day (this threshold value is from the Government of Vietnam) (Table S3). In particular, the selected households were interviewed to gather information on shifting cultivation including land use history, usable land area, productivity, and output. Additionally, information on costs and revenue from different crops (upland rice, corn, and cassava) were also collected and used in the cost-benefit analysis of shifting cultivation. For the second survey in 2018 in Quy Hop district, a total of 217 households in Chau Thai commune were interviewed to obtain further data on upland livelihoods in the forest system. As guided by the analytical framework (Figure 2), this second survey aimed at collecting a set of data points, including (i) household features and livelihood strategy, (ii) household income structure associated with the contribution of plantation forests, and (iii) constraints of forest practices for forest-planting households. 


\subsubsection{Carbon Data}

Plantation forests and shifting cultivation can capture carbon dioxide over time. Therefore, we took the carbon value into account in calculating the total economic value of land use options, which was the central part of the trade-off analysis. We began by searching the literature to obtain carbon information using four key criteria: land use types (plantation forests, shifting cultivation), up-to-date information (since 2000), complete information (name of trees, crops, planting year, length of one business cycle, interest rate), reliable data source (data were obtained from scientific articles, official publications, well-vetted sources). Among 52 relevant documents found after the first search, 20 key documents were used after further assessment. In addition, to fully assess the economic potential of plantation forests, we used the plantation forest carbon credit mechanism (PF-CCM) scenario adapted from the Afforestation and Reforestation-Clean Development Mechanism (AR-CDM) Cao Phong project [52]. Under the PF-CCM scheme, we used the tentative temporary certified emission reductions (tCERs) to measure the carbon value of plantation forests. Temporary certified emission reductions were calculated in light of the Cao Phong AR-CDM project [53,54].

We used field surveys to gather carbon sequestration data for shifting cultivation in Nghe An. We determined net carbon sequestration increments in the interval $\mathrm{I},(\mathrm{t} \mathrm{C})$, which is the difference between total cumulative carbon stored at the end of intervals I and I-1. We determined carbon at the end of the intervals in five pools: above-ground biomass (AGB); below-ground biomass (BGB); litter; dead wood; and soil pool. First, for the AGB and BGB, we collected data in a total of 18 representative $20 \times 20 \mathrm{~m}$ square plots. In each plot, five $2 \times 2 \mathrm{~m}$ square subplots were randomly selected without replacement for destructive collection of biomasses on fallow lands at 1, 2, 4, 6, 8, and 10 years. The total weight of the AGB and BGB was the sum of the mass of all organs of the tree/shrub, including mass of stems, branches, leaves, and roots. AGB was measured by collecting all AGB in each subplot. For BGB, in each subplot soils were extracted at a depth of $30 \mathrm{~cm}$. The roots were extracted from soils, which were then weighed. We randomly selected $500 \mathrm{~g}$ of roots to process dry biomass and carbon quantification. Biomass samples were taken to the Vietnam Forestry University laboratory to dry and calculate the amount of carbon stored. The dry weight of vegetation was determined by placing biomass samples in a drying oven at $105^{\circ} \mathrm{C}$ until they achieved a constant mass. After that, total dry biomass in vegetation was determined by aggregating the dry biomass of each organ in vegetation. The weight of carbon was assumed to be half of the dry weight of the biomass.

Secondly, deadwood and litter measurements were conducted in the same sample plots that tree measurements were conducted. Since there was no deadwood in the fallowed plots, it was excluded from carbon sequestration measurement. For litter measurement, we first placed the plot frame at the selected point, then we collected all litter inside the frame. A knife was used to cut pieces that crossed the border of the sampling frame. All litter was returned to the lab for dry weight quantification, following the protocols used for AGB and BGB. The weight of carbon of deadwood and litter was then assumed to be determined by multiplying the dry weight of the carbon pools by 0.37 [55].

Thirdly, in each representative plot, soil organic carbon (SOC) was determined by removing the coarse litter layer and using core sampler to take samples at 0-10, 10-20, and 20-30 cm depths. Next, all soils from the core sampler were transferred into a plastic bag, mixed, and sub-samples for dry weight quantification were removed, following the protocols for AGB and BGB. Soil organic carbon was determined by the multiplication of carbon concentration, soil depth, and bulk density. Lastly, the weight of sequestered carbon dioxide was determined by multiplying the weight of carbon in the vegetation by the ratio (3.76) of the mass of a carbon dioxide molecule $\left(\mathrm{CO}_{2}\right)$ to a carbon atom $(\mathrm{C})$. Total net carbon sequestration of shifting cultivation was determined, which was the sum of net carbon dioxide sequestered in the carbon pools of AGB, BGB, litter, and soil carbon. 


\subsection{Data Analysis and Empirical Methods}

\subsubsection{Forest Data Analysis}

We used the forest distribution map discussed in Section 4.2.1 for our analysis because it contains the best available forest data in Vietnam. It was constructed and validated at the national level with relatively high overall accuracy [50]. Forest distribution maps from 1990 to 2016 are constructed based on a land classification system of 13 land-use types: rich evergreen forest, medium evergreen forest, poor evergreen forest, rehabilitated forest, bamboo forest, mixed bamboo forest, limestone forest, plantation forest, limestone, bare land, waterbody, residential, and other lands. Each GIS map layer contains 13 land-use codes corresponding to the 13 land-use types listed above. To measure the area of forests, we used ArcGIS v10.2 (ESRI, CA, USA). We created both non-forest and forest maps by specifying query conditions at an initial time. We then created different maps of total forests, plantation forests, and natural forests by specifying query conditions at later time. We next employed 'intersect' and 'dissolve' commands in ArcGIS v10.2 to create data and a map of changes in plantation forests, natural forests, and total forests in Nghe An.

\subsubsection{Regression Models}

The sustainable livelihood framework was used to build an empirical model of household livelihood (measured by the gross household income) and their associated factors. The explanatory factors are drawn broadly from the categories of physical capital, social capital, human capital, natural capital, and financial capital [56]. We estimate a multiple regression model to uncover the relationship between household livelihood and the demographics as well as forest-related living conditions. After taking a natural log transformation of land-related variables (total forestland and rice land) and the total income to reduce the heavy skewness in their distributions, a multiple regression model with two-way interactions between every pair of variables was estimated using R version 3.6.3 [57]. The interactions that showed no statistical evidence of effects to the total income were dropped to create a more parsimonious model with the main effects and statistically significant interactions. Diagnostic tools were used to ensure that the assumptions associated with a regression model, such as linear relationship, normality, constant variance, etc., are adequately met. The final model has the following form:

$$
\begin{aligned}
& \ln (\text { Total income })=\beta_{0}+\beta_{1} I_{\text {Gender }=\text { Male }}+\beta_{2} \text { Age }+\beta_{3} \text { Education }+\beta_{4} \text { Labor size }+ \\
& \beta_{5} I_{\text {Bank loan }=\text { Yes }}+\beta_{6} I_{\text {Official }=\text { Yes }}+\beta_{7} I_{\text {Ag trained }=\text { Yes }}+\beta_{8} I_{\text {Allocated }=\text { Yes }}+\beta_{9} I_{\text {Self-allocated }=\text { Yes }}+ \\
& \beta_{10} I_{\text {Rent }=\text { Yes }}+\beta_{11} \text { Forestland }+\beta_{12} \text { Rice land }+\beta_{13}\left(\text { Age } \times I_{\text {Ag trained }=\text { Yes }}\right)+ \\
& \beta_{14}\left(I_{\text {Bank loan }=\text { Yes }} \times I_{\text {Ag trained }=\text { Yes }}\right)+\beta_{15}\left(I_{\text {Bank loan }=\text { Yes }} \times \text { Forestland }\right)+\varepsilon \text {, }
\end{aligned}
$$

where $\varepsilon$ is the error term and I's are the indicator variables taking the value of 1 when the associated binary predictor is true and 0 otherwise. Specifically, the explanatory variables are gender $\left(\beta_{1}\right)$, age $\left(\beta_{2}\right)$, and years of education of the household head $\left(\beta_{3}\right)$; family's labor size $\left(\beta_{4}\right)$, whether or not they have a bank loan $\left(\beta_{5}\right)$, whether or not they are an official $\left(\beta_{6}\right)$, whether or not they had agriculture training $\left(\beta_{7}\right)$, whether or not they were allocated forestland $\left(\beta_{8}\right)$, whether or not they had self-exploration land $\left(\beta_{9}\right)$, whether or not they rent forestland and rice land $\left(\beta_{10}\right)$, as well as the impact of the size of the forestland $\left(\beta_{11}\right)$ and riceland $\left(\beta_{12}\right)$ on total income. We also consider three interaction terms: age with agriculture training $\left(\beta_{13}\right)$, bank loan with agriculture training $\left(\beta_{14}\right)$, and bank loan with forestland $\left(\beta_{15}\right)$ because they have been shown to have a statistically significant effect on the total income. See the details of candidate variables used in the regression model of household income in Table S4.

\subsubsection{Trade-Off Analysis of Plantation Forest and Shifting Cultivation}

A trade-off analysis was used to evaluate land use options. This approach refers to the absolute value-based assessment (absolute advantage analysis) to find the Pareto optimal solutions among a set 
of estimated values associated with options or scenarios [58,59]. In many cases, an absolute advantage analysis may not be sufficient due to differentiated products-based advantage assessment (unique advantage analysis) [60]. Therefore, we first documented the unique advantages of each land use option (Table S5). For example, plantation forests produce wood while shifting cultivation provides food for farmers. Identification of unique advantages was the basis for the absolute advantage analysis, which we will describe in detail below.

The absolute advantage analysis began by using the total economic value approach [61,62] for valuing all products associated with each land-use option in Yen Na and Luong Minh communes. The total economic benefit of plantation forests is a sum of the Net Present Value (NPV) from wood products and the economic value of carbon for 15 years. The total economic benefit of shifting cultivation is a sum of the net present values of crops, such as rice, corn, and cassava. We assumed that farmers in the study area only cultivate crops for one year due to infertile land at the study sites; they return after a three to four-year fallowing; hence, we took a total of four times their cultivation into account for 15 years to calculate the NPV of shifting cultivation. Our discount rates for computing the NPV ranged from $0 \%$ to $15 \%$ as commonly used values for Vietnam $[27,28]$. Discount rates of $6.6 \%$ and $9.6 \%$ were included because they are based on the current preferential interest rates for poor farmers and small and medium-sized enterprises that invest in forest development plans [63]. Another important input for the empirical analysis was the economic value of carbon, which is highly linked to the carbon price on the global carbon market. Based on observations of the fluctuations in carbon prices and the tentative temporary certified emission reductions used in the Cao Phong AR-CDM project, we selected a carbon price interval of $\$ 0$ to $\$ 10$ per ha to estimate the economic value of carbon from tree-planting under PF-CCM. It is noted that the total economic benefit of tree-planting was calculated for all three communes, while the value of shifting cultivation was only calculated for Yen Na and Luong Minh communes because shifting cultivation is not practiced in Chau Thai commune. After obtaining the economic value associated with all components of plantation forests and shifting cultivation, a five-point heuristic spider diagram $[64,65]$ was used to illustrate the trade-off analysis. The spider diagram was shaped by seven dimensions corresponding to seven products of plantation forests and shifting cultivation. They are wood, carbon, food, wood revenue, carbon revenue, food revenue, and total revenue. Any dimension that contains the presence and absence of the differentiated products received a maximum point of 5 and a minimum point of 0 . The point of the remaining dimensions was proportionally assigned to the value of products within a five-point spider diagram.

\subsubsection{Principal Component Analysis}

Principal component analysis (PCA) was used to disentangle the multiple factors of forest practices at the household level. PCA is a multivariate analysis method, a technique for reducing the dimensionality of datasets while increasing interpretability and minimizing information loss $[66,67]$. Our usage of PCA began with reviewing literature combined with a pilot survey at the study sites in January 2018 to learn about plantation forests associated with relevant factors in Vietnam and other contexts. Although many factors affect plantation forests $[7,11,68]$; we ultimately retained only five key factor groups that influence plantation forest development in the study area. They are land capital, labor capital, forest seed (e.g., Acacia mangium), market, and agriculture extension service. Accordingly, we built a system of scale with a total of 34 Likert questions on a 5-point scale. These questions were designed to capture the five different levels of constraints of plantation forests. For example, the quality of land is shown on a 5-point scale in which 1 and 5 refer to the least and best quality of land, respectively. Explanatory factor analysis was then conducted to identify important variables and determine the factor group serving for the next step in the regression analysis. The PCA-based analysis was appropriate and efficient because our empirical diagnosis showed that the model satisfied five key criteria $[67,69]$, including reliability of the scale (Cronbach's alpha coefficient $>0.6$ ), reliability of the observed variable, verification of the model appropriateness $(0.5<$ Kaiser-Meyer-Olkin $(\mathrm{KMO})<1)$, inspection of Bartlett on correlation (Sig. $<0.5)$, and magnitude of cumulative variance ( $>50 \%)$. Principal 
component regression analysis was finally implemented to identify and rank by order the importance of constraints components (factors) of forest practices [69,70]. Detailed information on the PCA implementation is shown in Tables S6 and S7.

\section{Results}

\subsection{Forest Changes at the Communal Level in Nghe An}

(a)

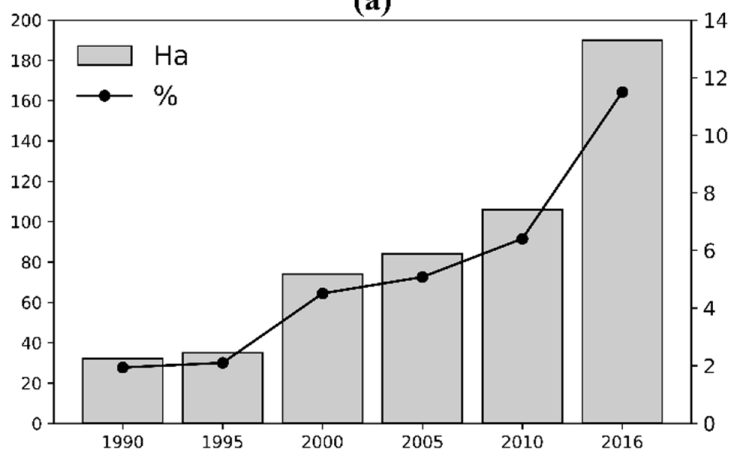

(c)

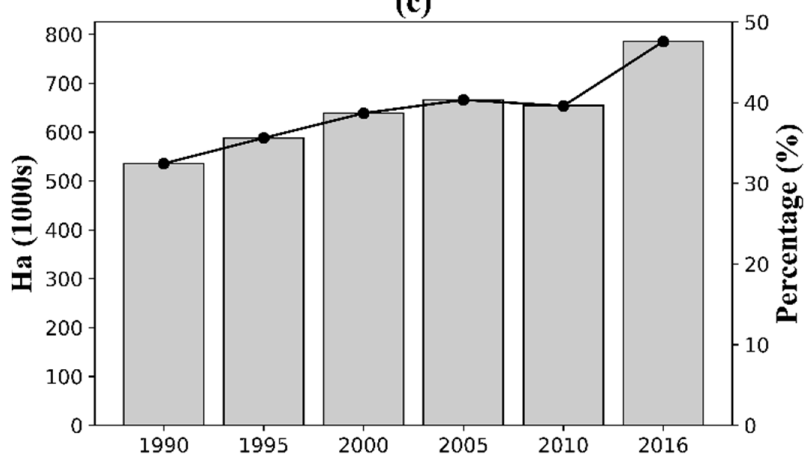

(e)

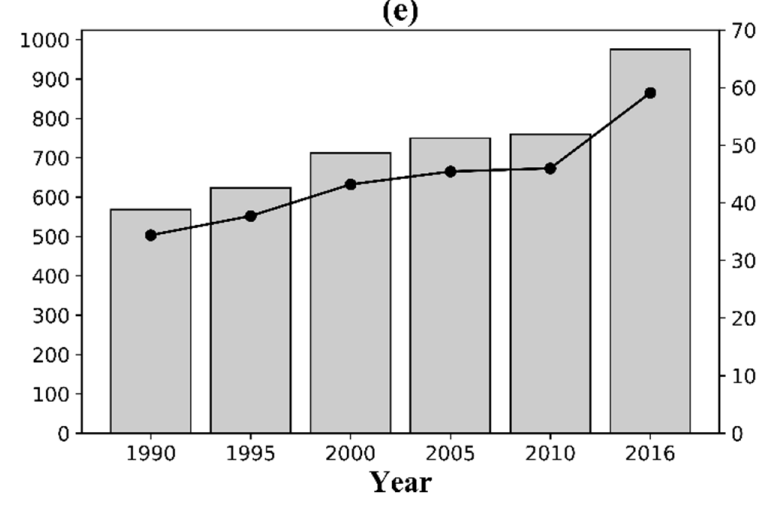

(b)

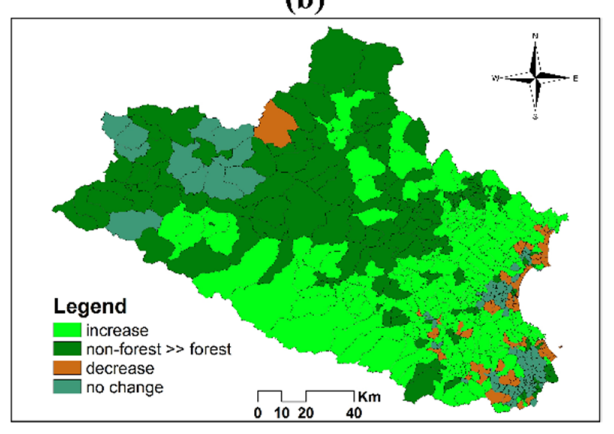

(d)

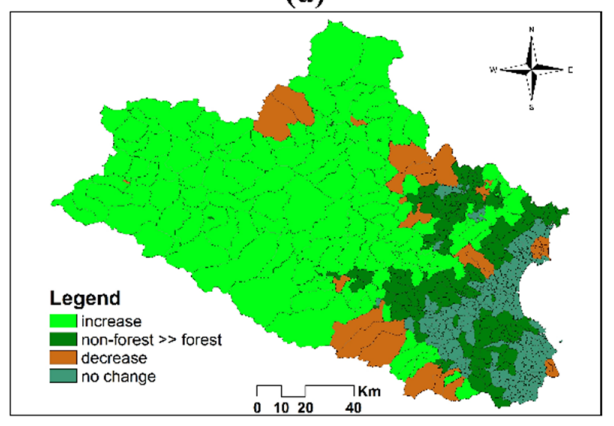

(f)

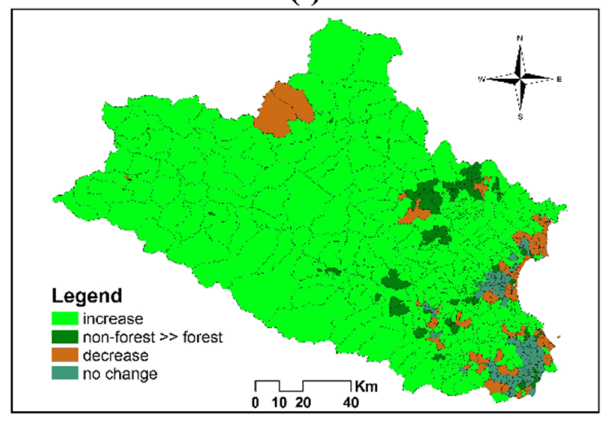

Figure 4. Change in plantation forests $(\mathbf{a}, \mathbf{b})$, natural forests $(\mathbf{c}, \mathbf{d})$, and total forests $(\mathbf{e}, \mathbf{f})$ in Nghe An. On figure (b,d,f), 'increase' and 'decrease' stand for the increase and decrease in aggregate forest area while 'non-forest >> forest' and 'no change' refer to the presence of forests from forestland-without-forests and unchanged aggregate forest area in communes respectively at the first (1990) and second measurement (2016).

To what extent do plantation forests increase and how much do they contribute to total forest cover? We examined the size of plantation forests in Nghe An between 1990 and 2016 to answer this research question. As shown in Figure 4, total forest area increased during this period by 406,000 ha, which is attributable to the expansion of natural forests and plantation forests. Natural forests expanded from 538,000 ha to 797,000 ha, while plantation forest increased from 32,000 ha to 190,000 ha. Total forest 
area experienced large annual fluctuations. The greatest change occurred during the period in 2010-2016 (4.7\%), followed by 1995-2000 (2.9\%), 1990-1995 (1.9\%), 2000-2005 (1\%), and 2005-2010 $(0.2 \%)$. While the total forest area has increased, the quality of natural forests is being also degraded. Plantation forests have expanded rapidly, but this type of forest occupied a relatively small share of Nghe An's land area. The share of plantation forests to total land area is about 2\% in 1990 and $11 \%$ in 2016. Plantation forests expanded mainly in communes that had a larger area of forest land associated with production forests and close to roads. Furthermore, those communes that had larger areas of forests in 1990 were likely to experience a higher forest cover afterwards. In addition, plantation forests occur much less frequently in the remote communes and poor communes.

\subsection{Household Income Associated with Plantation Forests}

How important are plantation forests to livelihoods? The following sections present empirical results of household livelihood studies in relation to plantation forests to answer this research question. Results include (i) household land use, (ii) household income structure, and (iii) determinants of household income and forest dependence.

\subsubsection{Land Use}

The forestland holdings of 217 households surveyed at four villages in Chau Thai commune is presented in Table 2. Forestland accounts for a relatively large share (88\%) of total land, while it differs across villages (Figure 3). On average, Ban Hat village had the highest percentage of forestland (92.84\%), followed by Thai Quang (91.03\%), Dong Minh (89.16\%), and Dong Hin (78.76\%). Forestland is unevenly distributed between the poor and the non-poor in three villages, yet at Dong Hin, forestland is allocated almost equally to both household groups (78.54\% and $78.97 \%)$. It is noted that the forestland allocation program has been implemented for many years in the upland, yet only $62.34 \%$ and $68.62 \%$ of the forestland has been certificated in Ban Hat and Thai Quang respectively. The percentage of allocated forestland in the surveyed poor households in Ban Hat and Dong Hin is 62.34\% and 89.40\% respectively, which indicates that implementation of the forestland allocation program may be different even within one commune.

Table 2. General characteristics of land of the surveyed households by villages at Chau Thai.

\begin{tabular}{cccccc}
\hline \multirow{2}{*}{ Groups } & \multirow{2}{*}{$\begin{array}{c}\text { Total } \\
\text { (Unit) }\end{array}$} & $\begin{array}{c}\text { Ban } \\
\text { Hat }\end{array}$ & $\begin{array}{c}\text { Dong } \\
\text { Hin }\end{array}$ & $\begin{array}{c}\text { Dong } \\
\text { Minh }\end{array}$ & $\begin{array}{c}\text { Thai } \\
\text { Quang }\end{array}$ \\
\hline Poor & ha & 192.41 & 82.54 & 79.89 & 119.0 \\
$(n=151)$ & $\%$ & 94.71 & 78.54 & 86.34 & 88.76 \\
& $\%$ & 62.34 & 89.40 & 77.28 & 68.62 \\
\hline Non-poor & ha & 90.02 & 7.76 & 106.82 & 87.25 \\
$(n=66)$ & $\%$ & 90.97 & 78.97 & 91.98 & 93.30 \\
& $\%$ & 83.60 & 89.77 & 84.78 & 84.41 \\
\hline
\end{tabular}

Note: The second row (\%) refers to the percentage of forestland of total household land. The third row (\%) refers to the percentage of certificated forestland of total household land.

Land uses by households are presented in Table 3. Household land is consisted of riceland, forestland, and other lands. Forestland comprises the largest area of total land for both poor and non-poor households. It is noted that forestland is statistically different between the two household groups; the forestland area of the non-poor is larger than that of the poor. 
Table 3. Land uses by household status at Chau Thai.

\begin{tabular}{|c|c|c|c|c|c|}
\hline Groups & Unit & Rice Land & Forest Land & Other Lands & Total Land \\
\hline $\begin{array}{c}\text { Poor } \\
(n=151)\end{array}$ & ha/HHs & $\begin{array}{c}0.09 \\
(0.06)\end{array}$ & $\begin{array}{c}2.96 \\
(3.76)\end{array}$ & $\begin{array}{c}0.09 \\
(0.13)\end{array}$ & $\begin{array}{c}3.14 \\
(3.80)\end{array}$ \\
\hline $\begin{array}{c}\text { Non-poor } \\
(n=66)\end{array}$ & ha/HHs & $\begin{array}{c}0.10 \\
(0.06)\end{array}$ & $\begin{array}{c}4.14 \\
(5.04)\end{array}$ & $\begin{array}{c}0.19 \\
(0.58)\end{array}$ & $\begin{array}{c}4.42 \\
(5.06)\end{array}$ \\
\hline Differences & ha/HHs & 0.001 & $1.18^{* * *}$ & 0.10 & $1.28^{* * *}$ \\
\hline
\end{tabular}

\subsubsection{Structure and Determinants of Household Income}

In Chau Thai commune, household income was attributed to seven sources: rice, livestock, garden, fish, plantation forest, hired (labor supply), and others (Table 4). Overall, the top three income sources were forests at $31.5 \%$, followed by hired (labor supply) at $27.3 \%$, and livestock at $25.1 \%$. There was a significant difference in gross household income for the poor versus the non-poor, yet there was no considerable difference in the contribution of plantation forests to total household income between the two groups, which are $35.1 \%$ (non-poor) and $27.8 \%$ (poor). Livestock was the largest income source for the poor $(32.1 \%)$ while the non-poor relied mostly on plantation forests $(35.2 \%)$ and hired labor-based income (35.1\%). For both household groups, plantation forests are the households' largest income source.

Table 4. Relation of plantation forest-based revenue to total household revenue by household group in Chau Thai commune.

\begin{tabular}{cccccccccc}
\hline \multirow{2}{*}{ Groups } & \multirow{2}{*}{ Unit } & \multicolumn{9}{c}{ Income Sources } & \multirow{2}{*}{$\begin{array}{c}\text { Total } \\
\text { Income }\end{array}$} \\
\cline { 3 - 9 } & & Rice & Livestock & Garden & Fish & Forest & Hired & Others & \\
\hline Poor & $\$ / \mathrm{HHs}$ & 146 & 288 & 4 & 18 & 249 & 176 & 15 & 896 \\
$(n=151)$ & $\%$ & 16.3 & 32.1 & 0.4 & 2.0 & 27.9 & 19.6 & 1.7 & 100 \\
\hline Non-poor & $\$ / \mathrm{HHs}$ & 151 & 463 & 7 & 11 & 899 & 896 & 131 & 2558 \\
$(n=66)$ & $\%$ & 5.9 & 18.1 & 0.3 & 0.4 & 35.2 & 35.1 & 5.1 & 100 \\
\hline Overall & $\$ / \mathrm{HHs}$ & 148 & 375 & 5 & 14 & 574 & 536 & 73 & 1727 \\
$(n=217)$ & $\%$ & 11.1 & 25.1 & 0.4 & 1.2 & 31.5 & 27.3 & 3.4 & 100 \\
\hline
\end{tabular}

In Chau Thai commune, after accounting for all other explanatory variables in the model (Table 5), the estimation results from the multiple regression show that there is no statistical evidence indicating that the head of a household, gender, age, and education level are associated with the total income of that household. Neither does having self-explored forestland that is explored by farmers themselves, leasing forestland, nor the area of rice land influences total household income. However, linear regression on data from Chau Thai commune indicated that total household income is significantly positively associated with the number of working age household members, access to bank loans, having an official role in the commune, agriculture training, having allocated forestland, and the size of forestland area. On average, when other independent variables were held constant, one more working household member is associated with $9 \%$ increase in household income (95\% confidence interval $(95 \%$ CI) from $2 \%$ to $17 \%$ ), having a bank loan is associated with $62 \%$ increase (95\% CI: $28 \%$ to $105 \%$ ), being an officer was $49 \%$ (95\% CI: $17 \%$ to $90 \%$ ), having agriculture training increased income by $172 \%$ (95\% CI: $31 \%$ to $463 \%$ ), being allocated forestland was $26 \%$ (95\% CI: $1 \%$ to $58 \%$ ), and one hectare increase in forestland resulted in 10\% (95\% CI: $5 \%$ to $14 \%$ ) increase in total household income. Among the interaction terms included in the refined model, we noticed that having a bank loan reduced the effect of forestland on total income. Specifically, the effect of a 1-hectare increase in forestland for a family with a loan is $8 \%$ (95\% CI: $3 \%$ to $12 \%)$ lower than that for a family without a loan. 
Table 5. Estimated multiple linear regression model and its $95 \%$ confidence interval (in parentheses) of total household income. The estimated effects were back-transformed in the rightmost column to facilitate interpretation.

\begin{tabular}{ccc}
\hline Variables & ln (Total Income) & Total Income \\
\hline Intercept) & $6.5(5.94,7.05)^{* * *}$ & $662.27(381.34,1150.18)^{* * *}$ \\
Gender = Male $\left(\beta_{1}\right)$ & $0.16(-0.01,0.33)$ & $1.18(0.99,1.39)$ \\
Age $\left(\beta_{2}\right)$ & $0(-0.01,0.01)$ & $1(0.99,1.01)$ \\
Education $\left(\beta_{3}\right)$ & $0(-0.03,0.02)$ & $1(0.97,1.02)$ \\
Labor size $\left(\beta_{4}\right)$ & $0.09(0.02,0.16)^{*}$ & $1.09(1.02,1.17)^{*}$ \\
Bank loan = Yes $\left(\beta_{5}\right)$ & $0.48(0.25,0.72)^{* * *}$ & $1.62(1.28,2.05)^{* * *}$ \\
Official role $=$ Yes $\left(\beta_{6}\right)$ & $0.4(0.16,0.64)^{* *}$ & $1.49(1.17,1.9)^{* *}$ \\
Agriculture training = Yes $\left(\beta_{7}\right)$ & $1(0.27,1.73)^{* *}$ & $2.72(1.31,5.63)^{* *}$ \\
Allocated forestland = Yes $\left(\beta_{8}\right)$ & $0.23(0.01,0.46)^{*}$ & $1.26(1.01,1.58)^{*}$ \\
Self-explored forestland = Yes $\left(\beta_{9}\right)$ & $0.19(-0.04,0.42)$ & $1.21(0.96,1.52)$ \\
Rent forestland = Yes $\left(\beta_{10}\right)$ & $0.02(-0.31,0.34)$ & $1.02(0.74,1.4)$ \\
Forestland (ha) $\left(\beta_{11}\right)$ & $0.09(0.05,0.13)^{* * *}$ & $1.1(1.05,1.14)^{* * *}$ \\
Rice land $\left(100 \mathrm{~m}^{2}\right)\left(\beta_{12}\right)$ & $0.01(0,0.02)$ & $1.01(1,1.02)$ \\
Age $\times$ Agriculture training $=$ Yes $\left(\beta_{13}\right)$ & $-0.02(-0.03,0)^{*}$ & $0.98(0.97,1)^{*}$ \\
Bank loan $=$ Yes $\times$ Agriculture & $-0.41(-0.72,-0.1)^{* *}$ & $0.66(0.49,0.9)^{* *}$ \\
training $=$ Yes $\left(\beta_{14}\right)$ & $-0.08(-0.13,-0.03)^{* * *}$ & $0.92(0.88,0.97)^{* * *}$ \\
Bank loan $=$ Yes $\times$ Forestland (ha) $\left(\beta_{15}\right)$ &
\end{tabular}

Note: ${ }^{* * *} p<0.001,{ }^{* *} p<0.01,{ }^{*} p<0.05$; Unit: VND.

\subsection{Trade-Offs of Land Use in Upland Communes}

\subsubsection{Agroforestry Products under Plantation Forests and Shifting Cultivation}

Food is the main agroforestry product from shifting cultivation. In Yen Na and Luong Minh communes, upland rice, corn, and cassava are the three main crops of shifting cultivation. In Yen $\mathrm{Na}$ commune, upland rice made up the largest area (15.18 ha), while cassava constituted the smallest area (1.5 ha) in local households' land use. A similar preponderance of upland rice was found in Luong Minh commune (9.38 ha), while corn accounted for the smallest area (1.5 ha). The land area owned by household groups is different, but the poor group owned larger land areas in both Yen Na and Luong Minh communes. Farmers earned different revenues from shifting cultivation in different locations. In Yen $\mathrm{Na}$, cassava provided the highest value $\left(\$ 403.2 \mathrm{ha}^{-1}\right)$, followed by upland rice $\left(\$ 190.6 \mathrm{ha}^{-1}\right)$ and corn $\left(\$ 107.8 \mathrm{ha}^{-1}\right)$. In Luong Minh, upland rice gained the most income ( $\left.\$ 278.3 \mathrm{ha}^{-1}\right)$, while cassava yielded the least revenue $\left(\$ 77.9 \mathrm{ha}^{-1}\right)$.

For forest product provision of plantation forests, we adopted and adapted the AR-CDM Cao Phong project [52] to obtain the data on two plantation forests species: Acacia auriculiformis and A. mangium. Generally, plantation forests can produce almost $254 \mathrm{~m}^{3}$ of wood per ha during an entire 15 -year cycle. A. auriculiformis $\left(270 \mathrm{~m}^{3}\right)$ produces a higher volume of wood than A. mangium $\left(238 \mathrm{~m}^{3}\right)$. This is because $A$. mangium does not have a second thinning in the 13th year [52].

\subsubsection{Carbon Sequestration Capacity of Plantation Forests and Shifting Cultivation}

The important value is the average carbon stock over multiple cycles, not the sequestration rate over one cycle. Shifting cultivation can store an average net of 4.29, [Standard Deviation (SD)] $=3.32 \mathrm{tCO}_{2} \mathrm{ha}^{-1} \mathrm{y}^{-1}$ for 15 years, while during a similar time frame, A. mangium and A. auriculiformis can store, on average, $12.02(\mathrm{SD}=12.15)$ and $13.72(\mathrm{SD}=22.39) \mathrm{tCO}_{2} \mathrm{ha}^{-1} \mathrm{y}^{-1}$, respectively. Average carbon stock increases over time and plantation forests outperform shifting cultivation during a 15 -year cycle. The difference in carbon sequestration capacity between plantation forests and shifting cultivation is significant, particularly between $A$. auriculiformis and shifting cultivation. 


\subsubsection{Comparison of Total Economic Value of Plantation Forests and Shifting Cultivation}

Total economic value (TEV) of plantation forests and shifting cultivation was computed and presented in Figure 5. Many TEV scenarios were taken into account as they are associated with different discount rates and carbon prices. Under the best condition (when the discount rate is at its lowest value and the carbon price is at its highest value), the TEV has the highest values in Yen $\mathrm{Na}$ commune (\$437.4 ha $\left.{ }^{-1} \mathrm{y}^{-1}\right)$ and Luong Minh commune $\left(\$ 335.4 \mathrm{ha}^{-1} \mathrm{y}^{-1}\right)$. For the most likely scenario (when the carbon price is between $\$ 2$ and $\$ 5$ and the discount rate is between $6 \%$ and $10 \%$ ), the TEV ranges from $\$ 42.1$ to $\$ 127.2 \mathrm{ha}^{-1} \mathrm{y}^{-1}$ for Yen Na commune and $\$ 29.1$ to $\$ 94.2 \mathrm{ha}^{-1} \mathrm{y}^{-1}$ for Luong Minh commune. The total economic value of plantation forests is higher than that of shifting cultivation at the popular discount rates, yet plantation forests are less profitable than shifting cultivation when the discount rate is equal to or greater than $12 \%$ for Yen Na commune and $11 \%$ for Luong Minh commune. These findings show that at lower discount rates plantation forests outperform shifting cultivation with respect to the associated total economic value. This suggests that farmers use higher discount rates to make their decision about whether to use land for shifting cultivation for plantation forest.
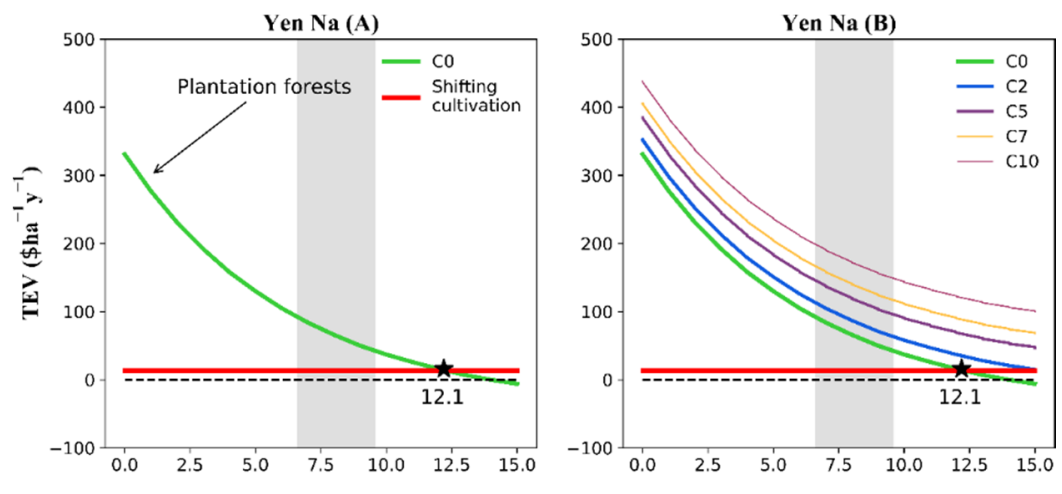

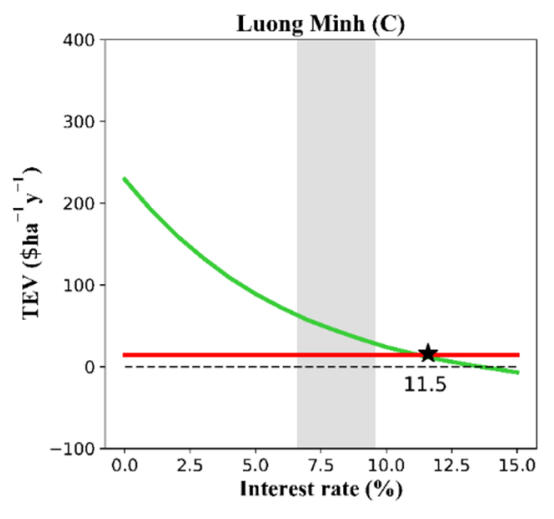

BAU

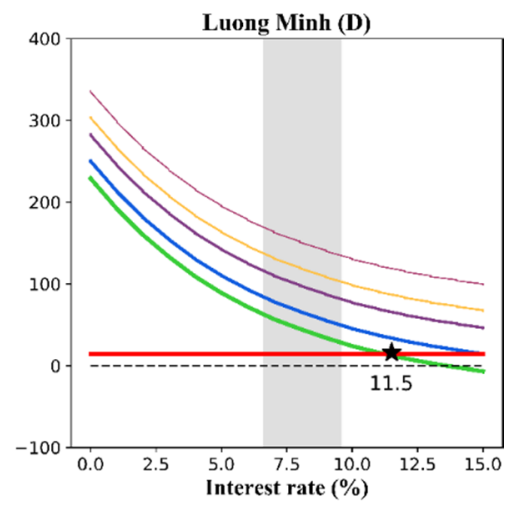

PF-CCM

Figure 5. Total economic value (TEV) of plantation forests and shifting cultivation under two scenarios: business as usual (BAU) in figures $(\mathbf{A}, \mathbf{C})$ and plantation forest carbon credit mechanism (PF-CCM) in figures (B,D). TEV of PF-CCM scenario is associated with a carbon price of $\$ 0$ to $\$ 10$. The shaded strip indicates the range of interest rate from $6.6 \%$ to $9.6 \%$ - the popular preferential interest rates for poor farmers and small and medium-sized enterprises that invest in forest development plans.

\subsubsection{Trade-Offs of Plantation Forests and Shifting Cultivation}

The trade-offs of plantation forests and shifting cultivation were evaluated through seven dimensions (Figure 6). As shown, plantation forests offer higher values than shifting cultivation in five dimensions (e.g., wood, wood-revenue, carbon, etc.) while shifting cultivation provides higher benefits than plantation forest in two dimensions (crop and crop-revenue). Besides, the highest benefit of plantation forest is provided at PF-CCM scenarios when taking carbon value into account. 

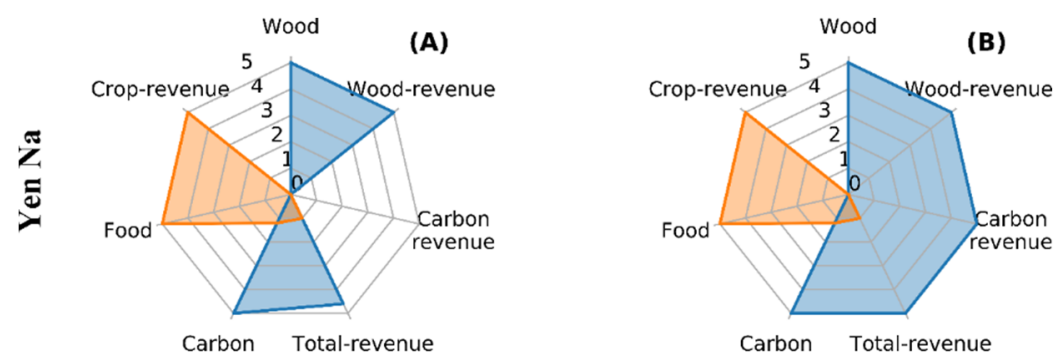

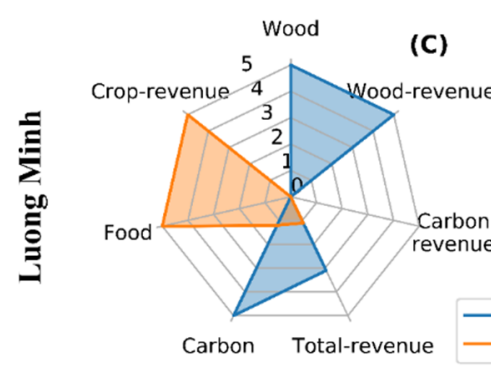

BAU

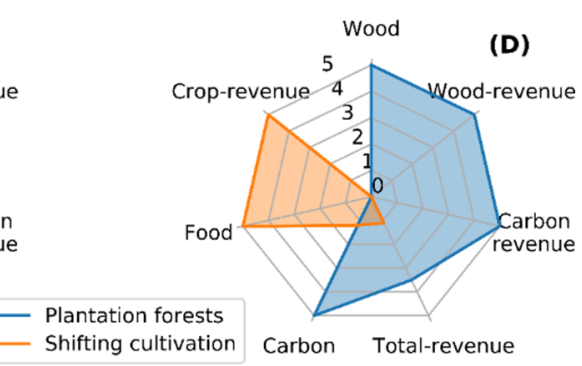

PF-CCM

Figure 6. Trade-offs of plantation forests and shifting cultivation. Crop and forest products provision associated with the business as usual (BAU) in figures $(\mathbf{A}, \mathbf{C})$ and plantation forest carbon credit mechanism (PF-CCM) scenario in figures (B,D) at studied communes. A 5-point scale heuristic spider diagram, which ranges from 0 (the lowest level) to 5 (the highest level), presents the absolute and unique advantage of each land-use option associated with seven respective components/indicators.

\subsection{Constraints for Plantation Forest Practices in Chau Thai Commune}

Given this analysis shows that plantation forests generally generate higher financial returns than shifting cultivation, what other factors constrain the uptake of plantations? This section presents empirical results of the constraints analysis to answer this research question. Most respondents stated that planting forests represent a moderate level of constraint, while a large proportion $(36.4 \%)$ of interviewed farmers claimed that planting plantation forests is very challenging. Assessment of plantation forest-related constraints is not the same for poor (3.2) and non-poor (2.8) households. Poor households were more likely than non-poor households to indicate that plantation forest practices were difficult.

Table 6 presents results of the importance of constraints on plantation forests in Chau Thai commune. The market price component was excluded in the restricted model due to no change in the residual variance. We mainly used results of the restricted model for interpretation. All components were ranked according to the coefficient values (transformed to \% unit) of the principal component regression model [69]. Among the top five constraints on plantation forests, the cooperation component was the most important factor (14.6\%), followed by financial capital $(14.2 \%)$, education (13.7\%), labor health (13.4\%), and market sustainability (12.7\%). Land capital, seedling, and agriculture extension component represent the lowest concerns for the farmers. 
Table 6. Rank the variables according to their importance.

\begin{tabular}{ccccccc}
\hline \multirow{2}{*}{ Component/Factor } & \multicolumn{3}{c}{ Full Model } & \multicolumn{3}{c}{ Restricted Model } \\
\cline { 2 - 7 } & Absolute Value & \% & Rank & Absolute Value & \% & Rank \\
\hline Financial capital & 0.295 & 13.6 & 2 & 0.295 & 14.2 & 2 \\
Agriculture extension & 0.137 & 6.3 & 8 & 0.137 & 6.6 & 8 \\
Market sustainability & 0.263 & 12.1 & 5 & 0.263 & 12.7 & 5 \\
House's location & 0.195 & 9.0 & 6 & 0.195 & 9.4 & 6 \\
Market price & 0.098 & 4.5 & 10 & - & - & - \\
Labor health & 0.278 & 12.8 & 4 & 0.278 & 13.4 & 4 \\
Seed quality & 0.128 & 5.9 & 9 & 0.128 & 6.2 & 9 \\
Land capital & 0.188 & 8.7 & 7 & 0.188 & 9.1 & 7 \\
Cooperation & 0.303 & 14.0 & 1 & 0.303 & 14.6 & 1 \\
Education & 0.284 & 13.1 & 3 & 0.284 & 13.7 & 3 \\
\hline
\end{tabular}

Note: all 10 components are included in the full model while market price is excluded in the restricted model. Financial capital refers to the constraint due to lack of money; the agriculture extension component is the difficulty associated with limited support by the agricultural extension office at the district and communal levels; market sustainability component refers to the constraint imposed by the unstable price of forest products on the market; and cooperation refers to the constraint due to limited exchange/sharing of information, knowledge, and technology in the field of forest practices among farmers within the local area. Absolute value is transformed into \%, which then results in ranking of components/factors.

\section{Discussion}

Plantation forests are increasingly contributing to total forest area in the north-central region in Vietnam; however, its share is relatively small (i.e., 11\% in 1990), particularly in poor communes. In these studied locales, there is a relatively large amount of unused land available for developing plantation forests (17.4\%). This finding reveals the opportunities and challenges related to increasing plantation forests in the uplands. The likelihood of plantation forest expansion is highly influenced by the economic incentive derived from forests [25,71], yet it may not be sufficient to make people more actively involved in forest practices.

Plantation forests practice has become an essential part of the livelihood strategy for farmers. For example, plantation forests account for almost $30 \%$ of total household income. This forest-planting activity not only illustrates the farmers' preference for plantation forests (A. mangium) to some extent but also provides them with an opportunity to gain valuable knowledge, techniques, and experiences in plantation forests [11]. Furthermore, it is no surprise that forestland is an important part of natural capital of household livelihood, and this is consistent with the finding that high forest-based income dependence is strongly correlated with larger forestlands. The big difference in forestland owned by the poor versus the non-poor raises the likely inequity issue about access to forestland. These findings, in part, reflect both the progress and shortcomings of the ongoing forestland allocation program designed to facilitate forestland ownership devolution in order to promote forest practices (Section 2) [72,73]. It is understandable that household income is attributable to the size of the labor force, while the dependence on forests is different for the poor and the non-poor. These findings demonstrate the dynamic complex socio-ecological system that has been seen in upland Vietnam [74,75], where livelihood strategy differs by household group based on the scale of natural capital (forest and forest land), human capital, financial capital, etc. More importantly, farmers may find it either easier to adopt or to expand plantation forests due to their accumulated knowledge, experience, possible economic incentives, and favorable conditions, which suggest that potential expansion of plantation forests can take place in similar remote places in Vietnam.

Plantation forests provide farmers an investment with many economic benefits under different conditions. High income from plantation forests has been found under the BAU scenario while the possible largest benefit of plantation forests has been examined for the PF-CCM scenario. This finding suggests that plantation forests could produce a larger economic benefit once accounting for the carbon value. It is noted that the economic benefit of plantation forests is associated with changes in 
carbon price and interest rate. While carbon price trends are highly volatile and difficult to predict, affecting uncertainty and unpredictability, and increase investor's risk level, the interest rate remains relatively high for the investor. For example, carbon price decreased from $\$ 20 \mathrm{tCERs}^{-1}$ in 1998 to $\$ 2$ $\mathrm{tCERs}^{-1}$ in 2012, while the current interest rate that the Vietnamese government has set for small and medium-sized enterprises (SMSE) is 9.6\%, and 6.6\% for SMSE investment in forest development [63]. In this regard, an investor may have to bear the financial constraints associated with high risks under the AR-CDM scheme [76]. Farmers are currently benefiting from planting forests when taking part in afforestation and reforestation programs (the Five-Million hectares Reforestation Program) [7], and this benefit is partially attributable to support from the government through rural credit associated with preferential interest loans [63]. Ongoing climate change projects have been piloting a carbon credit mechanism and payment for environmental services (Section 2) [13,26,77]; hence our results may help shape the required threshold carbon price that will enable the AR-CDM program to be more effective. More importantly, further economic benefits could be achieved through tree-planting practices under an appropriately improved rural credit policy and a reformed carbon credit mechanism [78,79].

Shifting cultivation offers food provision as a unique advantage value that plantation forests cannot offer. Shifting cultivation improves food security and provides additional income, while planting forests provide revenue, wood, firewood, and environmental values (Figure 6). The relative importance and preference for shifting cultivation versus tree-planting vary depending upon local and regional socioeconomic features and household livelihoods. Some farmers earn income from planting forests, then trade the income for food; this pathway is, however, impractical in isolated locations. Because people suffer from severe food shortages, food security is often more important than revenue. In this case, a farmer's preference for shifting cultivation is understandable. Shifting cultivation still remains common in Vietnam and other Southeast Asian countries for several reasons, but swidden systems have been changing with replacement by other forms of agriculture [80-82]. In cases where shifting cultivation is still practiced, fallow lengths usually become shorter. It is noteworthy that shifting cultivation has been a traditional mode of cultivation for local farmers; hence, the transformation from shifting cultivation to tree-planting may take time (years, decades, etc.) for many locals. This sociocultural, political factor may make farmers reluctant to get involved in plantation forest practices.

Our empirical findings reveal that the expansion of plantation forests in the upland areas is relatively promising. However, some other important challenges need to be mitigated. Many climate change mitigation programs such as reducing emission from deforestation and forest degradation (REDD+) and payment for forest ecosystem service (PFES) have been struggling and/or less successful due to low participation from farmers [13], which could be a valuable lesson for expanding plantation forests elsewhere. The possible reasons may vary from low economic motivation (see Section 2) to weak forestland tenure rights [73], and in addition, there is the issue of unsatisfied sociocultural and political demand [83]. Therefore, looking beyond economic-based incentive, it is important to answer successfully the fundamental questions (concerns) of how much rights do farmers have in their access to land, finance, market, information, and many other resources. In addition, due to various capital constraints (i.e., time, land, labor, finance, etc.), the need to balance between plantation forests, livestock, and food security is another challenge. First, this is because livestock is a major household income source (Section 5.2.2), so it is important to maintain livestock-grazing practices in order to annually sustain farmers' income before planters can harvest forest products from plantation forests. Second, the food market is not always convenient and accessible to farmers in some remote communes, so government intervention is required to secure food market to mitigate farmers' perennial concern of food scarcity. Sustainable livelihood depends on many factors including income diversification. A study in Chau Thai showed that people have many good short-term incomes. This is especially good news because forests are perennial and take some years to generate return. The presence of safety nets to absorb unexpected shocks would influence forest practices to some degree. However, some ongoing policies are doing well, for example, the poverty reduction program and the rural credit program. In addition, there is now an on-going "new rural program" that has achieved much success. The new 
rural program has promoted more comprehensive awareness in economic, social and environmental issues, so this provides an important foundation to continue to focus on developing plantation forests, taking advantage of strengths of the land and rural systems. All these findings are important because they advance our understanding of how to reconcile environmental and livelihood benefits [84] while providing valuable information on how to improve the level of support for forest protection activity in climate change mitigation projects as well as upcoming forest restoration projects, and they somewhat explain why there can be low participation from farmers in climate change mitigation programs [13]. Importantly, the finding facilitates and suggests that researchers and policymakers should include the many meaningful dimensions when conducting a trade-off analysis between plantation forests and shifting cultivation as the two mainland-use options in similar upland areas.

There are agroforestry models, that have been implemented in Southeast Asia, can help to facilitate forest expansion [85-88]. The agroforestry model takes advantage of short-term crops while waiting for the return of plantation forests. Although the agroforestry model is not a new one, the important thing is that it can enhance farmers' food security and short-term income, which is likely to help secure their livelihood when participating in afforestation. Therefore, the selection and replication of suitable agroforestry models with the support of the national agriculture and forestry extension system throughout the country are required to accelerate forest expansion. This approach seems to be relatively appropriate and sustainable for the poor localities as well as the study communes with high vulnerability, lack of food, and are geographically located away from city centers.

Survey respondents suggested that many factors hinder forest-planting, which is consistent with several studies conducted in the last decade for Vietnam [7,11,74]. The limitation in "cooperation and sharing" among farmers or between farmers and other stakeholders, such as small and medium enterprise, scientists, officers, etc., indicate that farmers are losing many benefits due to limited information (e.g., forest-product selling price). This finding suggests a cooperation policy to facilitate a win-win solution [89] based on social networks among stakeholders. The financial issue seems to be an enduring problem for most farmers. This is understandable because rural credit is not always well implemented, particularly in remote communes [44]. Although rural finance practice in Vietnam has recently improved [79], interest rates from $6 \%$ to $8 \%$ are common, which is a relatively high interest rate for farmers, especially for poor farmers. Furthermore, some farmers have to borrow money from black market credit agents [90]. These informal credit organizations offer short-term loans with high interest rates, causing adverse consequences for many households. Education and health were the next two major concerns for farmers in Yen Na and Luong Minh communes. For example, many pupils have dropped out of school, while many others are addicted to drugs (information obtained from field survey). A labor force with limited education and poor health may influence plantation forest practices. As expected, market stability becomes an important condition for securing more stable profits for farmers. Due to market instability associated with unclear information on selling prices, some farmers were forced to sell their forest products at a lower price and suffered losses. These findings all supplement and clarify the typical rural picture in Southeast Asian countries, where many constraints exist $[12,17,44,71,81]$, posing the need for many comprehensive collaborative adaptive policies in the immediate future.

We fully acknowledge the shortcomings of this paper including some caveats and limitations associated with data heterogeneity across time and space, omitted variables, sample size, undetected bias and uncovered relevant analysis. Firstly, the quality of some datasets associated with the forest map may contain some inaccuracy while there may have been errors in the socioeconomic data due to potential bias of respondents. Secondly, due to data availability issue, there are some missing valuable variables of social factors, such as migration, that could potentially be utilized in computing household income. Thirdly, the analysis relies on small sample size for the different time points which may influence the validity and reliability of the findings to some extent. Nghe An province has 206 poor communes [48], so studying 3 communes together with two land use options (shifting cultivation and plantation forests) may limit generalizations of potential plantation forest expansion in the upland 
area. Fourthly, because of resource and space limitations, this paper cannot cover desirable in-depth analysis in some other dimensions such as the linkages between plantations, shifting agriculture, incomes, plantation species, and broader political economy of plantation, the interaction and process associated with many socio-political factors that affect the farmer's participation in plantation forests or explain why many farmers are unwilling to get involved in plantation forests, which also limit the understanding of how forests could expand in upland communes.

Although there are some limitations, the insights from this study have made several theoretical, methodological, and policy contributions. Our research results provide crucial findings on forest development and upland rural livelihood improvement, which are key to ongoing sustainable development goals [91]. For example, increasing investments on forest practices could help support wood supply for the wood-exporting industry sector and increase income for nearly 30 million people in Vietnam (30\% of the population), who are living in mountain areas and are dependent on forests [74]. Additionally, improved income from forests not only supports farmers' wellbeing but facilitates successful agricultural transformation in Vietnam [40]. More importantly, this study identified factors associated with the expansion of plantation forests and the improvement of livelihoods that could be used in other regions of the world. Barriers to forest practices identified here are fundamental to understand, and this understanding could potentially benefit many ongoing national and international policies, projects and programs in Vietnam and beyond.

Our empirical results supplement the understanding of plantation forest-expanding solutions associated with the dynamic mountainous human forest systems or the upland complex socio-ecological systems [38,92]. For example, improving cooperation and sharing information, knowledge, and experiences in plantation forest practices would produce further social and economic benefits for the farmers, especially the poor farmers. The findings of the research keep the scholars, policymakers, and other actors informed of advanced information and understanding of the conditions and factors to promote afforestation and reforestation in remote mountainous areas. The research suggests a 'one-size-fits-all' policy would be inappropriate and/or impractical. Rather, a set of constantly improved policies is needed to help increase the necessary conditions (motivation and production inputs) and contributing conditions (constraints) for successful plantation forest practices. In unfavorable areas, the expansion of plantation forests is needed to overcome the constraints on reaching further economic and environmental goals, such as meeting a growing demand for wood. This is important because, in Vietnam, most of the fertile, favorable land is already planted or in use for development [52]. The implementation of plantation forests takes place slowly in barren or remote places far away from forest products-purchasing factories. From another perspective, this research identifies and promotes the likely solutions to achieving further forest transition irrespective of the state of a country's forests. For some countries, expanding plantation forests to achieve economic benefit is most beneficial, but for others, shortening the time length of forest transition based on plantation forests is highly desirable [17]. Furthermore, in the context of climate change, this research either facilitates or supplements the natural climate solutions to respond to a growing challenge from global climate change [1,3].

This research supplements the empirical synthesis approach by integrating different methods, suggesting the potential of this approach for similar future studies of mountainous socio-ecological systems that are inherently complex and diversified [38,93]. For example, the mixed method triangulation covers the absolute and unique advantage analysis, hence, it indeed becomes powerful in analyzing the trade-offs in land system science as normative science $[94,95]$. The insight from the research indicates that the integrated methods approach is highly appropriate for comprehensive research and is thus complementary to a novel synthesis method [45]. It is noted that the generalized knowledge claims are linked to the level of inference, conditions, and existing knowledge [96,97]; thus, a higher level of synthesis approach used for unraveling the problems of the complex socio-ecological systems would provide a better quality of the information or solutions desired. 


\section{Conclusions}

This study aimed to advance the knowledge about plantation forests expansion in remote mountainous regions in Vietnam by better understanding how planted forests contribute to total forest cover and household livelihoods, how plantation forests differ from shifting cultivation as an alternative land use option in terms of total economic value and carbon sequestration, and the constraints faced by forest planters. Despite resourcing and space limitation, this study represents the first effort in employing a mixed method triangulation approach to improve the quality of generalized claims for plantation forest expansion solutions. The empirical findings not only demonstrate the potential for plantation forest development in the study area but also reveal a policy gap in realizing the untapped income source of forest carbon value to increase total plantation forest value. In addition, our findings suggest that stronger policy is needed to overcome the identified constraints, especially regarding labor force, land, finance, and market. Furthermore, along with maintaining livestock practices, making the most efficient use of wet rice-land to improve and/or enhance food security to achieve sustainable livelihood would help farmers reduce the short-term income and food-demanding pressure, which could help facilitate faster transition from shifting cultivation to plantation forests. Plantation forests may have several negative social and environmental impacts [98,99], and their contribution in climate change mitigation is disputed [100,101], Yet, appropriately managed plantation forests can contribute to meet the growing demand for timber consumption, forests-based poverty reduction, and climate change mitigation $[1,102,103]$. This work contributes to science-based solutions to improve the socio-economic and environmental impacts of plantation forests. The link between forest transition (i.e., reforestation) and the national forest cover change is attributable to natural forest and plantation forest expansion, which are mainly driven by many stakeholders such as private companies and smallholders [16]. Hence this indicates that forest transition is highly associated with private decision making. Forest transition associated with deforestation and reforestation is a subset of a dynamic land use transition [15] and should be continuously studied to broadly complement and/or improve the middle range theory or generalized knowledge claims on land systems change in the near future $[96,104]$. Future work should advance the causal effects and mechanism analysis of forest transition $[104,105]$, in particular focusing on identifying the causal solutions of forest expansion at multiple scales. This is increasingly possible because methods of advanced model development have recently proliferated [45,106-109]. For example, qualitative comparative analysis, survival analysis, and propensity score matching could be used to quantify causal mechanisms and the timing of forest expansion, while panel data/time series data analysis could be used to identify what factors affect forest expansion and/or the factors affecting development of localized plantation forests. Another possible approach is using an agent-based model to unravel the causal relationship and dynamic interactions between key actors involved in forest practices, including households, state and private forest enterprises, and policy-makers while understanding the reasons why plantation forest implementation is less successful or ineffective in some regions. In addition to avoiding the limitations highlighted above, it is highly recommended to improve databases at multiple temporal-spatial scales for displaying spatially explicit research outcomes or likely solutions, and to use a computable general equilibrium model for advancing the understanding of the effects of a set of ongoing and future economic and environmental policies on forest transition and land-use change at national scales.

Supplementary Materials: The following are available online at http://www.mdpi.com/1999-4907/11/5/548/s1, Table S1: Forest area in Nghe An province; Table S2: Presence of forests in poor communes in Nghe An province, Vietnam; Table S3: Poverty line in Vietnam and the World in 2008-2020; Table S4: Descriptions of candidate variables used in the regression model of household income and forest dependence in uplands of Vietnam; Table S5: Products of plantation forests and shifting cultivation, associated with methods used to estimate them; Table S6: System of scale designed to collect the data to analyze the constraints of plantation forests using principal component analysis; Table S7: Results of explanatory factor analysis of components used to generate the factor groups. 
Author Contributions: Conceptualization, Q.V.K., T.H.N., D.N., B.Q.T., P.M., P.B.D., T.T.N., and M.W.P.; data curation, T.-A.T.L., B.Q.T., and B.T.M.N.; formal analysis, Q.V.K., T.-A.T.L., T.T. (Trung Tan), T.T. (Tan Tran) and T.-K.D.; Investigation, B.T.M.N.; methodology, Q.V.K., T.-A.T.L., T.H.N., D.N., P.M., T.T. (Trung Tran), P.B.D., T.T.N., T.T. (Tan Tran), L.P., S.L., N.T.P.T., T.-K.D., N.V.H. and H.-S.N.; project administration, T.-A.T.L., B.Q.T., and M.W.P.; supervision, B.Q.T., P.M., L.P., S.L. and M.W.P.; Validation, P.B.D., T.T. (Tan Tran), N.H.-D., N.V.H. and H.-S.N.; visualization, T.T. (Trung Tran); Writing-original draft, Q.V.K., T.-A.T.L., T.H.N., D.N. and T.T. (Tan Tran); Writing-review \& editing, Q.V.K., T.-A.T.L., T.H.N., D.N., B.Q.T., P.M., P.B.D., T.T.N., T.T. (Tan Tran), L.P., S.L., N.T.P.T., N.H.-D., T.-K.D., N.V.H., B.T.M.N., H.-S.N. and M.W.P. All authors have read and agreed to the published version of the manuscript.

Funding: This research received no external funding.

Acknowledgments: The authors would like to thank the collaborators of the University of Science, Vietnam National University, Vietnam National University of Forestry, Vietnam Academy of Forest Science, for their hard work on the field in Nghe An province. We especially thank many local families for their numerous supports during data collection. In Memory of the late friend André Dozier at Colorado State University, Fort Collins (1987-2019).

Conflicts of Interest: The authors declare no conflict of interest.

\section{References}

1. Griscom, B.W.; Adams, J.; Ellis, P.W.; Houghton, R.A.; Lomax, G.; Miteva, D.A.; Schlesinger, W.H.; Shoch, D.; Siikamäki, J.V.; Smith, P.; et al. Natural climate solutions. Proc. Natl. Acad. Sci. USA 2017, 114, 11645-11650. [CrossRef] [PubMed]

2. FAO. Managing forests for climate change. In The Dispersal and Social Exclusion Asylum Seekers: Between Liminality Belonging; Policy Press: Bristol, UK, 2011; pp. 1-19. [CrossRef]

3. Canadell, J.G.; Raupach, M.R. Managing forests for climate change mitigation. Science 2008, 320, $1456-1457$. [CrossRef]

4. Nguyen, T.T.; Pham, V.D.; Tenhunen, J. Linking regional land use and payments for forest hydrological services: A case study of Hoa Binh Reservoir in Vietnam. Land Use Policy 2013, 33, 130-140. [CrossRef]

5. Ripple, W.J.; Wolf, C.; Newsome, T.M.; Galetti, M.; Alamgir, M.; Crist, E.; Mahmoud, M.I.; Laurance, W.F. World Scientists' Warning to Humanity: A Second Notice. Bioscience 2017, 67, 1026-1028. [CrossRef]

6. Watson, J.E.M.; Venter, O. A global plan for nature conservation. Nature 2017, 550, 48-49. [CrossRef] [PubMed]

7. De Jong, W.; Sam, D.D.; Hung, T.V. Forest Rehabilitation in Vietnam: Histories, Realities and Future; Center for International Forestry Research: Jakarta, Indonesia, 2006; ISBN 9792446524.

8. MARD. Decision No. 3158/QĐ-BNN-TCLN. Proclaim about Forest Status in 2015; MARD: Hanoi, Vietnam, 2016.

9. MARD. Vietnam Forestry Development Strategy (2006-2020); MARD: Hanoi, Vietnam, 2007.

10. Cochard, R.; Ngo, D.T.; Waeber, P.O.; Kull, C.A. Extent and causes of forest cover changes in Vietnam's provinces 1993-2013: A review and analysis of official data. Environ. Rev. 2017, 25, 199-217. [CrossRef]

11. Sandewall, M.; Ohlsson, B.; Sandewall, R.K.; Viet, L.S. The expansion of farm-based plantation forestry in Vietnam. Ambio 2010, 39, 567-579. [CrossRef]

12. Bui, T.Y.; Visser, S.M.; Hoanh, C.T.; Stroosnijder, L. Constraints on Agricultural Production in the Northern Uplands of Vietnam. Mt. Res. Dev. 2013, 33, 404-415. [CrossRef]

13. Pham, T.T.; Moira, M.; Nguyen, T.H.; Nguyen, H.T.; Vu, T.H. The Context of REDD+ in Vietnam: Drivers, Agents and Institutions; Center for International Forestry Research: Bogor, Indonesia, 2015; ISBN 9786028693776.

14. Dao Minh, T.; Yanagisawa, M.; Kono, Y. Forest transition in Vietnam: A case study of the Northern mountain region. For. Policy Econ. 2017, 76, 72-80. [CrossRef]

15. Meyfroidt, P.; Lambin, E.F. Forest transition in Vietnam and its environmental impacts. Glob. Chang. Biol. 2008, 14, 1319-1336. [CrossRef]

16. Meyfroidt, P.; Lambin, E.F. The causes of the reforestation in Vietnam. Land Use Policy 2008, 25, $182-197$. [CrossRef]

17. Youn, Y.C.; Choi, J.; de Jong, W.; Liu, J.; Park, M.S.; Camacho, L.D.; Tachibana, S.; Huudung, N.D.; Bhojvaid, P.P.; Damayanti, E.K.; et al. Conditions of forest transition in Asian countries. For. Policy Econ. 2017, 76, 14-24. [CrossRef]

18. Nguyen, T.T. The impact of land reform on farm households in the Northern Uplands of Vietnam. Farming Rural Syst. Econ. Ser. 2008, 97, 213. 
19. Castella, J.C.; Boissau, S.; Thanh, N.H.; Novosad, P. Impact of forestland allocation on land use in a mountainous province of Vietnam. Land Use Policy 2006, 23, 147-160. [CrossRef]

20. Nguyen, T.V.; Tran, T.Q. Forestland and rural household livelihoods in the North Central Provinces, Vietnam. Land Use Policy 2018, 79, 10-19. [CrossRef]

21. Jakobsen, J.; Rasmussen, K.; Leisz, S.; Folving, R.; Quang, N.V. The effects of land tenure policy on rural livelihoods and food sufficiency in the upland village of Que, North Central Vietnam. Agric. Syst. 2007, 94, 309-319. [CrossRef]

22. Nguyen, T.T.; Bauer, S.; Uibrig, H. Land privatization and afforestation incentive of rural farms in the Northern Uplands of Vietnam. For. Policy Econ. 2010, 12, 518-526. [CrossRef]

23. Tran, T.; Vu, H. Van Land fragmentation and household income: First evidence from rural. Land Use Policy 2019, 89, 104247. [CrossRef]

24. Sikor, T.; Baggio, J.A. Can Smallholders Engage in Tree Plantations? An Entitlements Analysis from Vietnam. World Dev. 2014, 64, 101-112. [CrossRef]

25. Dinh, H.H.; Nguyen, T.T.; Hoang, V.; Wilson, C. Economic incentive and factors affecting tree planting of rural households: Evidence from the Central Highlands of Vietnam. www.opendocs.ids.ac.uk. J. For. Econ. 2017, 29, 14-24.

26. Simelton, E.S.; Catacutan, D.C.; Dao, T.C.; Dam, B.V.; Le, T.D. Factors constraining and enabling agroforestry adoption in Viet Nam: a multi-level policy analysis. Agrofor. Syst. 2017, 91, 51-67. [CrossRef]

27. Maraseni, T.N.; Son, H.L.; Cockfield, G.; Duy, H.V.; Nghia, T.D. Comparing the financial returns from Acacia plantations with different plantation densities and rotation ages in Vietnam. For. Policy Econ. 2017, 83, 80-87. [CrossRef]

28. Nguyen, T.T.; Koellner, T.; Le, Q.B.; Lambini, C.K.; Choi, I.; Shin, H.J.; Pham, V.D. An economic analysis of reforestation with a native tree species: The case of Vietnamese farmers. Biodivers. Conserv. 2014, 23, 811-830. [CrossRef]

29. Nguyen, M.D.; Ancev, T.; Randall, A. Forest governance and economic values of forest ecosystem services in Vietnam. Land Use Policy 2018, 1-17. [CrossRef]

30. Nielsen, M.R.; Theilade, I.; Meilby, H.; Nui, N.H.; Lam, N.T. Can PES and REDD+ match Willingness to Accept payments in contracts for reforestation and avoided forest degradation? The case of farmers in upland Bac Kan, Vietnam. Land Use Policy 2018, 79, 822-833. [CrossRef]

31. Pham, T.T.; Loft, L.; Bennett, K.; Phuong, V.T.; Dung, L.N.; Brunner, J. Monitoring and evaluation of Payment for Forest Environmental Services in Vietnam: From myth to reality. Ecosyst. Serv. 2015, 16, 220-229. [CrossRef]

32. Wurtzebach, Z.; Casse, T.; Meilby, H.; Nielsen, M.; Milhøj, A. REDD+ policy design and policy learning: The emergence of an integrated landscape approach in Vietnam. For. Policy Econ. 2018, 1-11. [CrossRef]

33. To, P.; Dressler, W. Rethinking 'success': The politics of payment for forest ecosystem services in Vietnam. Land Use Policy 2019, 81, 582-593. [CrossRef]

34. McElwee, P.D. Payments for environmental services as neoliberal market-based forest conservation in Vietnam: Panacea or problem? Geoforum 2012, 43, 412-426. [CrossRef]

35. Khuc, Q.; Tran, B.Q.; Meyfroidt, P.; Paschke, M.W. Drivers of deforestation and forest degradation in Vietnam: An exploratory analysis at the national level. For. Policy Econ. 2018, 90, 128-141. [CrossRef]

36. Do, D.S. Shifting Cultivation in Vietnam: Its Social, Economic and Environmental Values Relative to Alternative Land Use; IIED Forestry and Land Use Series No. 3; International Institute for Environment and Development (IIED): London, UK, 1994.

37. McElwee, P.D. Forests are Gold: Trees, People, and Environmental Rule in Vietnam; University of Washington Press: Seattle, WA, USA, 2016.

38. Sikor, T.; Nghiem, P.T.; Sowerwine, J.; Romm, J. Upland Transformations in Vietnam; NUS Press: Singapore, 2011.

39. Rudengren, J.; Huong, N.T.L.; Von Wachenfelt, A. Rural Development Policies in Vietnam: Transitioning from Central Planning to a Market Economy; Institute for Security and Development Policy: Stockholm, Sweden, 2012.

40. Laborde, D.; Lallemant, T.; Mcdougal, K.; Smaller, C. Transforming Agriculture in Africa E Asia: What Are the Policy Priorities? International Institute for Sustainable Development: Winnipeg, MB, Canada, 2018.

41. Garvican, L. Decision Theory: A Brief Introduction. Perspect. Public Health 1996, 133, 47-54. [CrossRef]

42. Holly, S.; Jorgenson, D.W.; Gollop, F.M.; Fraumeni, B. Productivity and US Economic Growth; North Holland: Amsterdam, The Netherlands, 2006; Volume 100, ISBN 0226043843. 
43. Baker, K.; Bull, G.Q.; Baylis, K.; Barichello, R. Towards a Theoretical Construct for Modelling Smallholders' Forestland-Use Decisions: What Can We Learn from Agriculture and Forest Economics? Forests 2017, 345. [CrossRef]

44. Pham, B.D.; Izumida, Y. Rural development finance in Vietnam: A microeconometric analysis of household surveys. World Dev. 2002, 30, 319-335. [CrossRef]

45. Magliocca, N.R.; Khuc, Q.V.; Ellicott, E.A.; De Bremond, A. Archetypical pathways of direct and indirect land-use change caused by Cambodia's economic land concessions. Ecol. Soc. 2019, 24. [CrossRef]

46. Bonnin, C.; Turner, S. Livelihood Vulnerability and Food Security among Upland Ethnic Minorities in Northern Vietnam. Philipp. J. Third World Stud. 2011, 26, 1-2.

47. Arouri, M.; Nguyen, C.; Youssef, A. Ben Natural Disasters, Household Welfare, and Resilience: Evidence from Rural Vietnam. WORLD Dev. 2015, 70, 59-77. [CrossRef]

48. PM. Decision No. 582/QĐ-TTg: Approving the List of Special Difficulty Communes within Area III, Area II, Area I in Ethnic Minority and Mountainous Region in 2016-2020; Chairman of the Committee for Ethnic Minority Affairs: Hanoi, Vietnam, 2017.

49. Truong, V. More than $80 \%$ of Acacia Area in Nghe An Is Sold When Tree Is Still Young. Available online: https://baonghean.vn/hon-80-dien-tich-keo-o-nghe-an-duoc-ban-la-keo-non-242020.html (accessed on 30 April 2020).

50. JICA. The Study on Potential Forests and Land Related to "Climate Change and Forests" in The Socialist Republic of Vietnam; JICA: Tokyo, Japan, 2012.

51. Lambert, S.D.; Loiselle, C.G. Combining individual interviews and focus groups to enhance data richness. J. Adv. Nurs. 2008, 62, 228-237. [CrossRef]

52. JICA. The Study on Capacity Development for AR-CDM Promotion in the Socialist Republic of Vietnam; Inception Report; JICA: Hanoi, Vietnam, 2008; p. 310.

53. UNFCCC Cao Phong Reforestation Project. 2012. Available online: https://cdm.unfccc.int/Projects/DB/ JACO1231473818.33/view (accessed on 5 January 2020).

54. UNFCCC AR-AMS0001: Simplified Baseline and Monitoring Methodologies for Small-Scale A/R CDM Project Activities Implemented on Grasslands or Croplands with Limited Displacement of Pre-Project Activities. 2006. Available online: https://cdm.unfccc.int/methodologies/DB/91OLF4XK2MEDIRIWUQ2 (accessed on 5 January 2020).

55. IPCC. Guidelines for National Greenhouse Gas Inventories; Prepared by the National Greenhouse Gas Inventories Programme; Eggleston, H.S., Buendia, L., Miwa, K., Ngara, T., Tanabe, K., Eds.; IGES: Hayama, Japan, 2006.

56. DFID. Sustainable Livelihoods Guidance Sheets; Department for International Development: London, UK, 1999.

57. R Core Team R: A Language and Environment for Statistical Computing. 2019. Available online: https: //www.R-project.org/ (accessed on 5 January 2020).

58. Eskelinen, P.; Miettinen, K. Trade-off analysis approach for interactive, nonlinear multiobjective optimization. OR Spectr. 2012, 34, 803-816. [CrossRef]

59. Nguyen, T.H.; Cook, M.; Field, J.L.; Khuc, Q.V.; Paustian, K. High-resolution trade-off analysis and optimization of ecosystem services and disservices in agricultural landscapes. Environ. Model. Softw. 2018, 107, 105-118. [CrossRef]

60. Penson, J.B., Jr.; Capps, O.T., Jr.; Rosson, C.P., III; Woodward, R.T. Introduction to Agricultural Economics; Prentice Hall, Inc.: Upper Saddle River, NJ, USA, 2006; Volume 1, ISBN 9780133379488.

61. Plottu, E.; Plottu, B. The concept of Total Economic Value of environment: A reconsideration within a hierarchical rationality. Ecol. Econ. 2007, 61, 52-61. [CrossRef]

62. Costanza, R.; Arge, R.; DeGroot, R.; Farberk, S.; Grasso, M.; Hannon, B.; Limburg, K.; Naeem, S.; Neill, R.V.O.; Paruelo, J.; et al. The value of the world 's ecosystem services and natural capital. Nature 1997, 387, 253-260. [CrossRef]

63. VBSP. Interest Interest for Loan. 2017. Available online: http://vbsp.org.vn (accessed on 5 January 2020).

64. Howe, C.; Suich, H.; Vira, B.; Mace, G.M. Creating win-wins from trade-offs? Ecosystem services for human well-being: A meta-analysis of ecosystem service trade-offs and synergies in the real world. Glob. Environ. Chang. 2014, 28, 263-275. [CrossRef]

65. DeFries, R.S.; Asner, G.P.; Houghton, R. Trade-offs in land-use decisions: Towards a framework for assessing multiple ecosystem responses to land-use change. Geophys. Monogr. Ser. 2004, 153, 1-9. [CrossRef] 
66. Jolliffe, I.T.; Cadima, J. Principal component analysis: A review and recent developments. Philos. Trans. R. Soc. A 2016, 374, 16. [CrossRef]

67. Williams, B.; Onsman, A.; Brown, T. Education Exploratory factor analysis: A five-step guide for novices. J. Emerg. Prim. Heal. Care 2010, 8, 2010-990399.

68. Krishnapillay, D.B. Case Study of the Tropical Forest Plantations in Malaysia; FAO: Rome, Italy, 2002; Volume 40.

69. Dinh, P.H. Quantitative Research Methods and Practical Studies in Agricultural Economic Development; Phuong Dong: Ho Chi Minh City, Vietnam, 2012.

70. Liu, R.X.; Kuang, J.; Gong, Q.; Hou, X.L. Principal component regression analysis with SPSS. Comput. Methods Programs Biomed. 2003, 71, 141-147. [CrossRef]

71. Nguyen, T.T.; Do, T.L.; Bühler, D.; Hartje, R.; Grote, U. Rural livelihoods and environmental resource dependence in Cambodia. Ecol. Econ. 2015, 120, 282-295. [CrossRef]

72. Dang, T.K.P.; Visseren-Hamakers, I.J.; Arts, B. Forest devolution in Vietnam: From rhetoric to performance. Land Use Policy 2018, 77, 760-774. [CrossRef]

73. To, P.X.; Tran, N.H.; Zagt, R. Forest Land Allocation in Viet Nam: Implementation Processes and Results. Preservation 2013, 2, 1-16.

74. Dinh, D.T. Forestry, Poverty Reduction, and Rural Livelihoods in Vietnam; Labour and Social Affair Publishing House: Hanoi, Vietnam, 2005.

75. Trædal, L.T.; Vedeld, P. Cultivating forests: The role of forest land in household livelihood adaptive strategies in the Bac Kan Province of northern Vietnam. Land Use Policy 2018, 73, 249-258. [CrossRef]

76. Thomas, S.; Dargusch, P.; Harrison, S.; Herbohn, J. Why are there so few afforestation and reforestation Clean Development Mechanism projects? Land Use Policy 2010, 27, 880-887. [CrossRef]

77. Tckukpi, C.; Cpf, C.; Vq, E.; Ocpcigogpv, V.J.G.; Korngogpvcvkqp, C.P.F.; Vjg, Q.H. Vietnam's Green Future Payments for Forest Environmental Services (PFES) in Vietnam Findings from Three Years of Implementation. 2008. Available online: www.vnff.mard.gov.vn (accessed on 5 January 2020).

78. Höhne, N.; Warnecke, C.; Day, T.; Röser, F. Carbon Market Mechanisms in Future International Cooperation on Climate Change; New Climate Institute: Cologne, Germany, 2015.

79. Ta, N.L.; Long, H.T.; Chi, L.V.; Tam, L.T.; Lebailly, P. Access to rural credit markets in developing countries, the case of Vietnam: A literature review. Sustainability 2019, 11, 1468. [CrossRef]

80. Li, P.; Feng, Z.; Jiang, L.; Liao, C.; Zhang, J. A review of swidden agriculture in Southeast Asia. Remote Sens. 2014, 6, 1654-1683. [CrossRef]

81. Erni, C. Shifting Cultivation Livelihood and Food Security: New and Old Challenges for Indigenous People in Asia; Food and Agriculture Organization of the United Nations and International Work Group for Indigenous Affairs and Asia Indigenous Peoples Pact: Bangkok, Thailand, 2015; ISBN 9789251087619.

82. Dressler, W.H.; Wilson, D.; Clendenning, J.; Cramb, R.; Keenan, R.; Mahanty, S.; Bruun, T.B.; Mertz, O.; Lasco, R.D. The impact of swidden decline on livelihoods and ecosystem services in Southeast Asia: A review of the evidence from 1990 to 2015. Ambio 2017, 46, 291-310. [CrossRef] [PubMed]

83. Sikor, T. Tree plantations, politics of possession and the absence of land grabs in Vietnam. J. Peasant Stud. 2012, 39, 1077-1101. [CrossRef]

84. Meyfroidt, P. Trade-offs between environment and livelihoods: Bridging the global land use and food security discussions. Glob. Food Sec. 2018, 16, 9-16. [CrossRef]

85. Phimmavong, S.; Narayan, T.; Keenan, R.J.; Cockfield, G.; Science, F.; Nuol, P.D.R.; Box, P.O.; Democratic, L. Land Use Policy Financial returns from collaborative investment models of Eucalyptus agroforestry plantations in Lao PDR. Land Use Policy 2019, 87, 104060. [CrossRef]

86. Ran, R.F. Enhancing the food security of upland farming households through agroforestry in Claveria, Misamis Oriental, Philippines. Agrofor. Syst. 2010, 79, 327-342. [CrossRef]

87. Thang, H.V.; Do, T.V.; Kozan, O.; Catacutan, D.C. Cost-Benefit Analysis for Agroforestry Systems in Vietnam. Asian J. Agric. Ext. Econ. Sociol. 2015, 5, 158-165. [CrossRef]

88. Bui, N.; Nguyet, M.; Quy, K.V.; Khang, L.N.; Le, S.D.; Nguyen, Q.H. The economic and environmental performances of agroforestry land-use models in Dak Nong province. J. For. Sci. Technol. 2019, 8, 157-164.

89. Sunderlin, W.D.; Belcher, B.; Santoso, L.; Angelsen, A.; Burgers, P.; Nasi, R.; Wunder, S. Livelihoods, forests, and conservation in developing countries: An overview. World Dev. 2005, 33, 1383-1402. [CrossRef]

90. Loc, L.P.; Thi, N.; Linh, H.; Le, T.; An, H. Household debt in Vietnam: An overview. In Household Debt in SEACEN Economies; SAECEN: Kuala Lumpur, Malaysia, 2011; pp. 169-193. 
91. UN. The UN Sustainable Development Goals; United Nations: New York, NY, USA, 2015. Available online: http://www.un.org/sustainabledevelopment/summit/ (accessed on 5 January 2020).

92. Redman, C.L.; Grove, J.M.; Kuby, L.H. Integrating social science into the Long-Term Ecological Research (LTER) Network: Social dimensions of ecological change and ecological dimensions of social change. Ecosystems 2004, 7, 161-171. [CrossRef]

93. Rindfuss, R.R.; Walsh, S.J.; Turner, B.L.; Fox, J.; Mishra, V. Developing a science of land change: Challenges and methodological issues. Proc. Natl. Acad. Sci. USA 2004, 101, 13976-13981. [CrossRef] [PubMed]

94. Nielsen, J.; de Bremond, A.; Roy Chowdhury, R.; Friis, C.; Metternicht, G.; Meyfroidt, P.; Munroe, D.; Pascual, U.; Thomson, A. Toward a normative land systems science. Curr. Opin. Environ. Sustain. 2019, 38, 1-6. [CrossRef]

95. Verburg, P.H.; Erb, K.H.; Mertz, O.; Espindola, G. Land System Science: Between global challenges and local realities. Curr. Opin. Environ. Sustain. 2013, 5, 433-437. [CrossRef] [PubMed]

96. Magliocca, N.R.; Ellis, E.C.; Allington, G.R.H.; de Bremond, A.; Dell'Angelo, J.; Mertz, O.; Messerli, P.; Meyfroidt, P.; Seppelt, R.; Verburg, P.H. Closing global knowledge gaps: Producing generalized knowledge from case studies of social-ecological systems. Glob. Environ. Chang. 2018, 50,1-14. [CrossRef]

97. Vuong, Q.H.; Napier, N.K. Acculturation and global mindsponge: An emerging market perspective. Int. J. Intercult. Relat. 2015, 49, 354-367. [CrossRef]

98. Bernhard-Reversat, F. Effect of Exotic Tree Plantations on Plant Diversity and Biological Soil Fertility in the Congo Savanna; Center for International Forestry Research: Jakarta, Indonesia, 2001; ISBN 9798764722.

99. Liu, C.L.C.; Kuchma, O.; Krutovsky, K.V. Mixed-species versus monocultures in plantation forestry: Development, benefits, ecosystem services and perspectives for the future. Glob. Ecol. Conserv. 2018, 15, e00419. [CrossRef]

100. Ellis, B.E.C.; Maslin, M.; Lewis, S. Planting Trees Won't Save the World. New York Times, 12 February 2020; pp. 12-13.

101. Skidmore, A.K.; Wang, T.; de Bie, K.; Pilesjö, P. Comment on "The global tree restoration potential". Science 2019, 366, 1-5. [CrossRef] [PubMed]

102. The World Bank Meeting the Growing Demand for Forest Products: Plantation Forestry and Harvesting Operations in Natural Forests. For. Sourceb. Pract. Guid. Sustain. For. Dev. Coop. 2008, 402. [CrossRef]

103. Bastin, J.-F.; Finegold, Y.; Garcia, C.; Mollicone, D.; Rezende, M.; Routh, D.; Zohner, C.M.; Crowther, T.W. The global tree restoration potential. Science 2019, 365, 76-79. [CrossRef] [PubMed]

104. Meyfroidt, P.; Roy Chowdhury, R.; de Bremond, A.; Ellis, E.C.; Erb, K.H.; Filatova, T.; Garrett, R.D.; Grove, J.M.; Heinimann, A.; Kuemmerle, T.; et al. Middle-range theories of land system change. Glob. Environ. Chang. 2018, 53, 52-67. [CrossRef]

105. Meyfroidt, P. Approaches and terminology for causal analysis in land systems science. J. Land Use Sci. 2016, 11, 501-522. [CrossRef]

106. Paitan, C.P.; Verburg, P.H. Methods to assess the impacts and indirect land use change caused by telecoupled agricultural supply chains: A review. Sustainability 2019, 11, 1162. [CrossRef]

107. Magliocca, N.R.; Khuc, Q.V.; de Bremond, A.; Ellicott, E.A. Direct and indirect land-use change caused by large-scale land acquisitions in Cambodia. Environ. Res. Lett. 2020, 15, 024010. [CrossRef]

108. Vuong, Q.; La, V.; Nguyen, M.; Ho, M. Improving Bayesian statistics understanding in the age of Big Data with the bayesvl R package. Softw. Impacts 2020, 4, 100016. [CrossRef]

109. Nong, D.; Simshauser, P. On energy and climate change policies: The impact of baseline projections. Appl. Energy 2020, 269, 115062. [CrossRef]

(C) 2020 by the authors. Licensee MDPI, Basel, Switzerland. This article is an open access article distributed under the terms and conditions of the Creative Commons Attribution (CC BY) license (http://creativecommons.org/licenses/by/4.0/). 